\title{
The Liver under the Spotlight: Bile Acids and Oxysterols as Pivotal Actors Controlling Metabolism
}

\author{
Charlotte Lefort (D) and Patrice D. Cani * D \\ Metabolism and Nutrition Research Group, Louvain Drug Research Institute, Walloon Excellence in Life Sciences \\ and BIOtechnology (WELBIO), UCLouvain, Université Catholique de Louvain, Av. E. Mounier, 73 B1.73.11, \\ 1200 Brussels, Belgium; Charlotte.lefort@uclouvain.be \\ * Correspondence: Patrice.cani@uclouvain.be; Tel.: +32-2-764-73-97
}

check for

updates

Citation: Lefort, C.; Cani, P.D. The Liver under the Spotlight: Bile Acids and Oxysterols as Pivotal Actors Controlling Metabolism. Cells 2021, 10, 400. https://doi.org/10.3390/ cells10020400

Academic Editor: Marianna Crispino

Received: 22 January 2021

Accepted: 12 February 2021

Published: 16 February 2021

Publisher's Note: MDPI stays neutral with regard to jurisdictional claims in published maps and institutional affiliations.

Copyright: (c) 2021 by the authors. Licensee MDPI, Basel, Switzerland. This article is an open access article distributed under the terms and conditions of the Creative Commons Attribution (CC BY) license (https:/ / creativecommons.org/licenses/by/ $4.0 /)$.

\begin{abstract}
Among the myriad of molecules produced by the liver, both bile acids and their precursors, the oxysterols are becoming pivotal bioactive lipids which have been underestimated for a long time. Their actions are ranging from regulation of energy homeostasis (i.e., glucose and lipid metabolism) to inflammation and immunity, thereby opening the avenue to new treatments to tackle metabolic disorders associated with obesity (e.g., type 2 diabetes and hepatic steatosis) and inflammatory diseases. Here, we review the biosynthesis of these endocrine factors including their interconnection with the gut microbiota and their impact on host homeostasis as well as their attractive potential for the development of therapeutic strategies for metabolic disorders.
\end{abstract}

Keywords: liver; bile acids; oxysterols; inflammation; gut microbiota; steatosis; cholesterol; lipid metabolism; glucose metabolism

\section{Introduction}

The liver, by being the first organ exposed to molecules absorbed from the intestine, plays a vital role in the detoxification of harmful substances (e.g., toxins and xenobiotics) and in the regulation of energy homeostasis [1,2]. This metabolic hub of the body displays an extensive number of signaling pathways mediated by over a dozen of cell types in different proportions with distinct roles [3]. The hepatocytes are the major parenchymal cells of the liver. They are the functional units of this organ and represent $60 \%$ of the total liver cells but occupy $80 \%$ of the liver volume [4]. These cell types are essential and can manage numerous and various physiological processes (e.g., detoxification, bile acid (BA) synthesis, regulation of glucose and lipid metabolism). Hepatocytes are the biggest cell type of the liver (i.e., 20-40 $\mu \mathrm{m}$ ) and have a life span of at least 150 to 200 days in humans and up to 450 days in rodents [4]. Aside from hepatocytes, the liver is also composed of biliary epithelial cells and sinusoidal cells. Specifically, sinusoidal cells, including liver sinusoidal endothelial cells (LSECs), Kupffer cells (KCs) and hepatic stellate cells (HSCs), constitute about $30-40 \%$ of total liver cell number and $6.5 \%$ of the liver volume [4]. LSECs lie along the sinusoids and have the particularity of possessing pores, also called fenestrae, which mainly filter the molecules of the blood for the hepatocytes [5]. KCs are the resident macrophages of the liver. Under physiological conditions, they act as sentinels and have the capacity, for instance, to clear endotoxins coming from the gut lumen to defend the liver [6]. Finally, HSCs contribute to fibrogenesis and play a major role in the production of the extracellular matrix [3,7]. Altogether, the liver is an intricate organ composed of a complex network of various cell types which need to be properly regulated to maintain an appropriate body homeostasis.

In this review, we will mainly focus on the role played by the hepatocytes on the production of different bioactive lipids such as BAs and oxysterols. We will summarize the major pathways involved in the production of these molecules in both physiological and pathological conditions. We will also report how the oxysterol/BA profiles vary during 
metabolic and inflammatory disorders and their consequences on the host metabolism. Ultimately, the recent therapeutic strategies designed to tackle metabolic disorders using compounds able to modulate BA metabolism will be delineated.

\section{Biosynthesis of Oxysterols and BAs}

The liver is an organ of utmost importance for the regulation of cholesterol concentration since it is the main tissue involved in both its production and metabolization. At high levels, cholesterol is toxic and can damage the surrounding cells. One efficient way to eliminate this excess from the body is to convert it into its oxidized derivatives, that are oxysterols and BAs which are playing different metabolic roles [8,9]. In fact, the most described function for BAs regards lipid assimilation in the gut. Indeed, after meal ingestion, these molecules are secreted into the duodenum and facilitate the digestion and absorption of dietary fat, steroids and fat-soluble vitamins [8]. However, this role is far from being unique as detailed later in this review.

Oxysterols are early oxygenated forms of cholesterol or of its precursors that are generated through enzymatic (e.g., cytochrome (CYP) P450s and cholesterol 25-hydroxylase $\mathrm{Ch} 25 \mathrm{OH}$ ) and non-enzymatic reactions (e.g., reactive oxygen species (ROS)) [10,11]. Oxysterols resulting from these reactions can be structurally different and divided in several groups including monohydroxycholesterols, dihydroxycholesterols, epoxycholesterols or ketone derivatives (Figure 1A) [12]. Although they were long considered as simple intermediates in the formation of BAs (e.g., 25-hydroxycholesterol (OHC) and $7 \alpha-\mathrm{OHC})$ and steroid hormones (e.g., 22(R)-OHC), they also act as signaling mediators. These related activities will be addressed in detail later in this review. Of interest, their synthesis is not restricted to hepatocytes since some have also been detected in immune cells and neurons, among others [12].

Unlike oxysterols, primary BAs are only generated in hepatocytes through an elaborate network involving at least 17 enzymes (Figure 1) [13]. There are two main routes producing primary BAs: the classic and the alternative pathways. In humans, the classic pathway accounts for approximately $90 \%$ of total BA production whereas the alternative pathway contributes for the remaining $10 \%$ under normal physiological condition. In rodents, however, both cascades participate equally to the synthesis of BAs [14,15]. 
A



\begin{tabular}{|c|c|c|c|c|}
\hline & R1 & R2 & R3 & $\mathrm{R} 4$ \\
\hline $24(S)-\mathrm{OHC}$ & $\mathrm{OH}$ & $\mathrm{H}$ & $\mathrm{H}$ & $\mathrm{H}$ \\
\hline 25-ОНС & $\mathrm{H}$ & $\mathrm{OH}$ & $\mathrm{H}$ & $\mathrm{H}$ \\
\hline 27-OHC & $\mathrm{H}$ & $\mathrm{H}$ & $\mathrm{OH}$ & $\mathrm{H}$ \\
\hline $7 \alpha-\mathrm{OHC}$ & $\mathrm{H}$ & $\mathrm{H}$ & $\mathrm{H}$ & $\mathrm{OH}(\alpha)$ \\
\hline
\end{tabular}

\section{B}

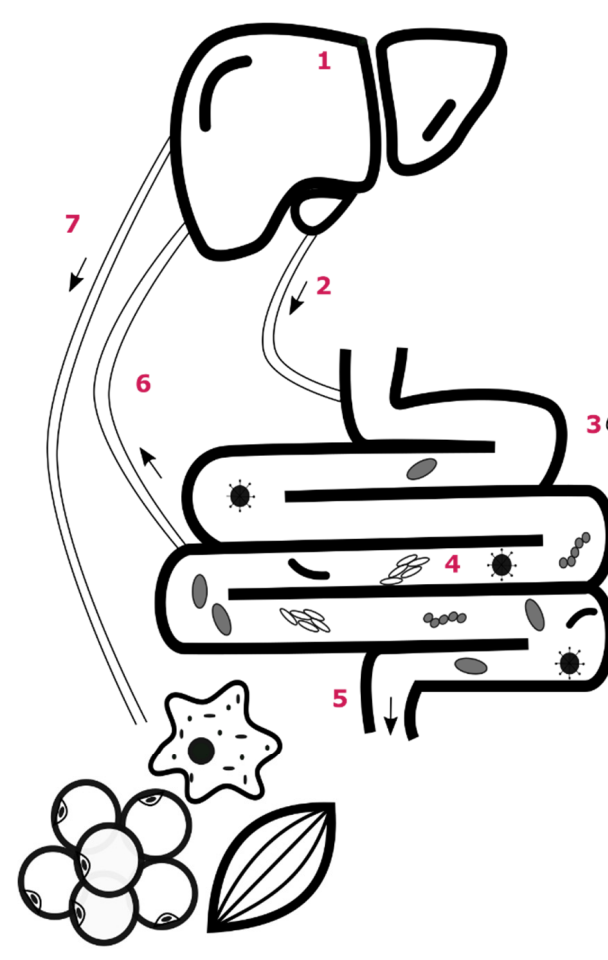



\begin{tabular}{|c|c|c|c|}
\hline & R1 & R2 & R3 \\
\hline CA & $\mathrm{OH}(\alpha)$ & $\mathrm{OH}(\alpha)$ & $\mathrm{H}$ \\
\hline CDCA & $\mathrm{H}$ & $\mathrm{OH}(\alpha)$ & $\mathrm{H}$ \\
\hline DCA & $\mathrm{OH}(\alpha)$ & $\mathrm{H}$ & $\mathrm{H}$ \\
\hline LCA & $\mathrm{H}$ & H & $\mathrm{H}$ \\
\hline
\end{tabular}

\begin{tabular}{|c|c|c|c|}
\hline & R1 & R2 & R3 \\
\hline UDCA & $\mathrm{H}$ & $\mathrm{OH}(\beta)$ & $\mathrm{H}$ \\
\hline$\alpha-$ MCA & $\mathrm{H}$ & $\mathrm{OH}(\alpha)$ & $\mathrm{OH}(\beta)$ \\
\hline$\beta$-MCA & $\mathrm{H}$ & $\mathrm{OH}(\beta)$ & $\mathrm{OH}(\beta)$ \\
\hline$\omega-M C A$ & $\mathrm{H}$ & $\mathrm{OH}(\beta)$ & $\mathrm{OH}(\alpha)$ \\
\hline
\end{tabular}

(1)

Oxysterol and primary BA synthesis in hepatocytes Cholesterol

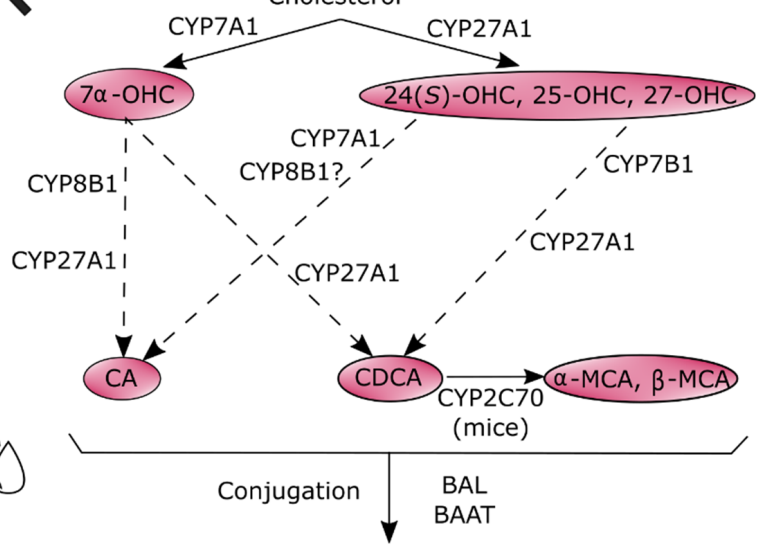

$\mathrm{G}(\mathrm{T}) \mathrm{CA}, \mathrm{G}(\mathrm{T}) \mathrm{CDCA}, T \alpha-M C A, T_{\beta}-\mathrm{MCA}$



Secondary BA synthesis by the gut microbiota

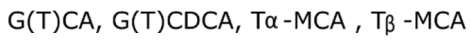

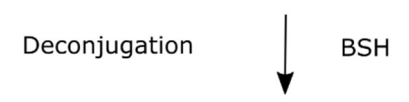

CA, CDCA, $\alpha-M C A, \beta-M C A$

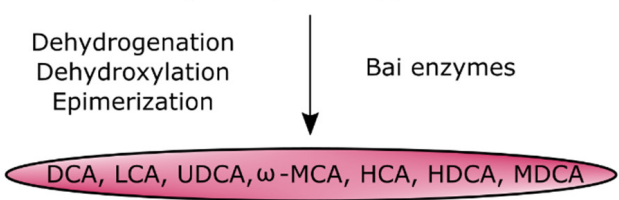

Figure 1. Overview of oxysterol and bile acid (BA) metabolism. (A) Structure of the main oxysterols and BAs involved in host homeostasis modulation. (B) Biosynthesis and circulation of oxysterols and BAs. (1) Primary BAs are generated from oxysterols through numerous enzymes (e.g., CYP7A1, CYP27A1, CYP7B1 and CYP8B1) in hepatocytes, are then conjugated with T or G by BAL and BAAT and finally stored in the gallbladder. (2) Upon meal ingestion, these are released into the duodenum. (3) BAs can facilitate lipid absorption. (4) Some primary BAs are deconjugated and then converted into secondary BAs by specific intestinal bacteria. (5) While approximately 5\% are excreted, (6) about 95\% are reabsorbed and travel back to the liver via the portal vein. (7) Finally, a small proportion of BAs reaches other organs (e.g., muscles and adipose tissue) through the systemic circulation. Abbreviations: BA, bile acid; BAAT, bile acid CoA:amino acid $\mathrm{N}$-acyltransferase; Bai, bile acid-inducible; BAL, bile acid CoA ligase; BSH, bile salt hydrolase; CA, cholic acid; CDCA, chenodeoxycholic acid; CYP, cytochrome P450 enzyme; DCA, deoxycholic acid; G, glycine-conjugated species; HCA, hyocholic acid; HDCA, hyodeoxycholic acid; LCA, lithocholic acid; MCA, muricholic acid; MDCA, murideoxycholic acid; $\mathrm{OHC}$, hydroxycholesterol; T, taurine-conjugated species; UDCA, ursodeoxycholic acid. 
On the one hand, the classic pathway initiates with the rate-limiting enzyme named cholesterol $7 \alpha$-hydroxylase (CYP7A1) and aims to produce both cholic acid (CA) and chenodeoxycholic acid (CDCA) $[13,16]$. The sterol $12 \alpha$-hydroxylase (CYP8B1) is also a key enzyme of this cascade since it is required to form CA and is, therefore in charge of regulating the $\mathrm{CA} / \mathrm{CDCA}$ ratio [17]. On the other hand, the alternative pathway regulates oxysterol levels by synthesizing 24(S)-OHC, 25-OHC and 27-OHC (also known as 26-OHC) through the transporter steroidogenic acute regulatory protein (StarD1) and the enzyme sterol 27-hydroxylase (CYP27A1) [18]. These bioactive lipids are thereafter metabolized mainly by oxysterol $7 \alpha$-hydroxylase (CYP7B1) to predominantly generate CDCA. Noteworthy, in rodents, ursodeoxycholic acid (UDCA) is considered as a primary BA and CDCA is mostly converted to $\alpha$-muricholic acid (MCA) and $\beta$-MCA by CYP2C70, a $6 \beta$-hydroxylase enzyme recently identified $[13,18,19]$. Once formed, primary BAs are conjugated with glycine in humans and taurine in rodents by bile acid CoA:amino acid N-acyltransferase (BAAT) and excreted into the biliary canaliculi via the ABC-transporter bile salt export pump (BSEP) to ultimately be stored in the gallbladder [15]. These amphipathic molecules are secreted into the duodenum after a meal but most of the conjugated BAs are then actively reabsorbed in the distal ileum by the apical sodium-dependent bile salt transporter (ASBT), travel back to the liver through the portal blood, are taken up by the $\mathrm{Na}^{+}$-dependent taurocholate transporter (NTCP) in hepatocytes to finally be secreted in the gallbladder. This phenomenon is called the enterohepatic circulation. However, a small proportion of BAs escapes this reabsorption and are profoundly affected by the gut microbiota in the ileum and colon. Conjugated BAs are firstly deconjugated by bacterial bile salt hydrolases (BSHs) present in a large variety of bacteria including both Gram-negative (e.g., Bacteroides) and Gram-positive genera (e.g., Clostridium, Lactobacillus, Listeria and Enterococcus) [20]. Free BAs can either cross the gut barrier through passive diffusion or be further processed by bacterial enzymatic activities (e.g., dehydrogenation and dehydroxylation), increasing the catalogue of BA molecules. Indeed, CA and CDCA are metabolized by the bacterial $7 \alpha-$ dehydroxylase, that removes their $7 \alpha-\mathrm{OH}$ group, to form secondary BAs, deoxycholic acid (DCA) and lithocholic acid (LCA), respectively [15]. Additionally, in humans' gut, CDCA can also be biotransformed into UDCA by $7 \beta$-hydroxysteroid dehydrogenase (HSDH) which epimerizes its $7 \alpha-\mathrm{OH}$ into a $7 \beta-\mathrm{OH}$ group. Besides, oxo-BAs can also be generated by $3 \alpha, 7 \alpha$ and $12 \alpha$-HSDHs which epimerize the corresponding $\alpha-\mathrm{OH}$ group to carbonyl group. These oxo-BAs can be further metabolized into iso-BAs and epi-BAs trough the $\beta$-epimerization of the carbonyl group thanks to $3 \beta, 7 \beta$ and $12 \beta$-HSDHs [20]. In mice, murine-specific primary BAs, $\alpha$-MCA and $\beta$-MCA, can be converted into secondary BAs as well. Although both can generate murideoxycholic acid (MDCA), only $\beta$-MCA can be metabolized into $\omega$-MCA, hyocholic acid (HCA) and hyodeoxycholic acid (HDCA) [15]. These bacterial metabolites can also be passively absorbed from the gut and can impact the whole organism by acting as signaling molecules (this will be discussed in a subsequent section of this review). In total, $\sim 95 \%$ of the total BAs are reabsorbed at some point, whereas $\sim 5 \%$ are excreted in the feces [8]. Of interest, in the mouse liver, LCA and DCA can be converted back to CDCA and CA, respectively, through rehydroxylation, by the recently described 7 $\alpha$-hydroxylase (CYP2A12) [19]. Finally, it is worth mentioning that in an adult human liver, around $500 \mathrm{mg}$ of cholesterol is daily catabolized into BAs [13].

\section{Physiological Roles of BAs on Energy Homeostasis and Inflammation}

\subsection{BA Profile in Inflammatory and Metabolic Diseases}

BAs are amphipathic molecules and their hydrophobicity level can be classified according to this order $\mathrm{LCA}>\mathrm{DCA}>\mathrm{CDCA}>\mathrm{CA}>\mathrm{HDCA}>\mathrm{UDCA}>\beta-\mathrm{MCA}>\alpha-\mathrm{MCA}$, free species being more hydrophobic than conjugated BAs (glycine-conjugated $>$ taurine-conjugated) [20-22]. One of their primary function regards their ability to digest and absorb lipid-related molecules in the intestine [15]. Nevertheless, in humans, changes in BA profile have also been widely observed in patients suffering from obesity and associated comorbidities (e.g., nonalcoholic fatty liver disease (NAFLD), nonalcoholic steatohepatitis (NASH) and type 
2 diabetes (T2DM)). For instance, individuals with metabolic disorders usually have an increase in total BA pool [23]. This has been largely reported in NAFLD/NASH patients in several compartments such as the liver, serum and feces [24-27]. Besides, the enlargement of the BA pool has recently been associated with the progression of the disease $[28,29]$. Paradoxically it should be mentioned that an elevated BA pool is not always associated with deleterious health effects given that humans undergoing bariatric surgery are characterized by a rise in BA levels while their metabolic parameters are improving [30]. Moreover, although obesity-related disorders are usually characterized by a chronic low-grade inflammation, individuals with chronic intestinal inflammatory diseases (e.g., Crohn's disease (CD) and ulcerative colitis (UC)) exhibit another BA profile. Indeed, in inflammatory bowel diseases (IBD), it has been clearly demonstrated that the deconjugation and thus the conversion of primary to secondary BAs were impaired resulting in an increased conjugated primary BA level [31-33]. This suggests that the location and severity of inflammation might also influence the BA composition.

Coming back to the role of BAs on lipid absorption, it has been established that the composition of BAs released in the intestine influence this function, that can in turn, have an impact on energy homeostasis. Indeed, it has been reported that hydrophobic BAs only produced by the classic pathway and thereby hydroxylated on their C12 (also known as 12-OH BAs), including CA and its microbial-derivative DCA, enhance the absorption of fat and cholesterol in mice by forming efficiently mixed and larger micelles, respectively (Figure 2A) [22,34,35]. This could substantially aggravate metabolic parameters in obesityrelated diseases. Conversely, it has recently been demonstrated that UDCA administration in mice, a non 12-OH BA, exerted beneficial metabolic outcomes by increasing the rate of BA enterohepatic circulation and excretion leading to an accelerated BA synthesis and a diminished cholesterol level in the liver [36]. Additionally, by administering BAs from the alternative pathway instead of the classic pathway in mice, it has been demonstrated that an elevated concentration of the hydrophilic non 12-OH BAs, MCAs and UDCA, resulted in a decreased intestinal fat and cholesterol absorption [22]. In line with this, it has been shown that serum 12-OH BAs were augmented in humans with insulin resistance [37]. Moreover, a reduction in non 12-OH BA plasma level was found in unhealthy individuals with high body mass index (BMI) (i.e., $\geq 25 \mathrm{~kg} / \mathrm{m}^{2}$ ) compared to healthy subjects with low or high BMI [38]. Curiously, it should be noted that the ratio 12-OH/non 12-OH rose in the serum of obese who lost weigh in spite of a reduction in their total BA level [39]. Overall, promoting the alternative pathway to manage metabolic disorders seems promising as recently reviewed by Jia and colleagues [40]. However, one should bear in mind that enhancing this alternative pathway may have different consequences on mice compared to humans since CDCA (in humans) and MCA (in mice) exhibit different hydrophobicity level and opposing effects on one BA receptor called farnesoid X receptor (FXR) (this receptor will be extensively discussed later in this review). Further investigations are definitely required to clarify it.

Noteworthy, among all the studies mentioned here above, we noticed some discordances in BA profile associated with one specific disorder. Although this is not clearly addressed in these clinical research, we do believe that these differences may be due to the feeding state of the person (i.e., fasting versus postprandial measurements), the use of drugs influencing the gut microbiota and/or the liver function (e.g., metformin, statins and proton-pump inhibitors), the technique of measurement (e.g., untargeted versus targeted studies), biological sample analyzed (e.g., plasma versus stool), gender and age as well as the severity of the disease.

Collectively, this suggests that BAs might display context-dependent roles and it strengthens the importance of deciphering the exact functions of these bioactive lipids that potentially may be used as future treatments to counteract either inflammatory or metabolic disorders. 




Figure 2. BAs and oxysterols at the nexus of host homeostasis. (A) BA profile in the intestine regulates lipid assimilation with 12-OH BAs promoting fat and cholesterol absorption. Conversely, the composition of the diet also influences BA profile since total BAs is increased upon high-fat diet (HFD) exposure. (B) A mutual relationship exists between the gut microbiota and BAs. BAs regulate the proliferation, maturation and the composition of the intestinal bacteria while the gut microbiota generates secondary BAs. Displaying a healthy equilibrium is essential since bacterial metabolites including secondary BAs are impacting host metabolism. (C) BAs and oxysterols are considered as signaling molecules since they can interact with a panel of receptors distributed in the whole body. The BA receptors FXR, TGR5 and VDR as well as the oxysterol receptor LXR are the most important ones regarding inflammatory and metabolic disorders. Abbreviations: BA, bile acid; CA, cholic acid; DCA, deoxycholic acid; FXR, farnesoid X receptor; GLP-1, glucagon-like peptide 1; LXR, liver X receptor; MCA, muricholic acid; OH, hydroxyl group; TGR5, Takeda G-protein coupled receptor 5; UDCA, ursodeoxycholic acid; VDR, vitamin D receptor.

\subsection{BAs as Endocrine Molecules}

Apart from playing a key role in lipid absorption, it is now recognized that BAs act as signaling mediators influencing host homeostasis by interacting with both a $G$ protein coupled receptor named TGR5 (Takeda G-protein coupled receptor 5) and various nuclear receptors such as FXR, vitamin D receptor (VDR), constitutive androstane receptor (CAR) or pregnane $X$ receptor (PXR). While PXR and CAR are mostly associated with drug 
metabolism and detoxification, it has been proven that FXR, TGR5 and VDR mediate pleiotropic effects in inflammation and energy metabolism (Figure 2C) [14,16].

\subsubsection{Farnesoid X Receptor (FXR)}

FXR is expressed in various tissues including the liver (i.e., hepatocytes> LSECs, HSCs and KCs), intestine (i.e., enterocytes from ileum > colon), kidneys, adipose tissue, adrenal glands, cardiovascular system and lungs. However, its role has mostly been investigated in the tissues taking part in the BA enterohepatic circulation [16]. FXR is activated by several BAs such as CDCA, DCA, CA and LCA with unconjugated BAs being more potent FXR activators than conjugated BAs [41-44]. Although this latter fact remains stable across studies, controversial data have been published regarding the ranking of FXR-activating BAs. This difference might vary according to the in vitro/in vivo conditions, organisms, FXR isoforms and sometimes pathological situations. Indeed, several in vitro studies carried out on cell lines from different organisms (e.g., humans and monkeys) have drawn the conclusion that FXR-activating BA rank was the following CDCA > DCA > LCA > CA [41-44]. In mice, according to an in vivo study investigating the expression of several hepatic and ileal FXR-target genes following the ingestion of specific BA at different doses, CA and DCA were greater FXR activators than CDCA and LCA and differed in a dose-dependent manner [45]. Strikingly, in NASH/NAFLD patients, despite the higher amount of total BAs and consequently FXR agonists, FXR activity is diminished [26,46]. Jiao and colleagues have suggested that DCA might act as FXR antagonist in the presence of CDCA in humans with NASH [26]. It is also worth noting that, in mice, T $\alpha / \beta$-MCAs have been reported to act as FXR antagonists [47].

- FXR and BA Regulation

The synthesis of BAs is under the control of a negative feedback loop. When entering in enterocytes, ileal FXR is activated and enhances the expression of both the intestinal bile acid-binding protein (I-BABP) [44], and the organic solute transporter (OST) $\alpha$ and OST $\beta$ that are basolateral BA transporters leading to an efflux of BAs in the portal vein. More importantly, intestinal FXR activation also promotes the secretion of the intestinal fibroblast growth factor (FGF)15 in mice (FGF19 in humans) [14]. Subsequently, this small molecule is conveyed to the portal circulation and reaches the liver to activate the fibroblast growth factor receptor (FGFR) $4 / \beta$-Klotho receptor that represses CYP7A1 and CYP8B1 through extracellular signal-regulated kinase (ERK) and c-Jun N-terminal kinase (JNK) stimulation leading to the suppression of BA synthesis (Figure 3) [48-50]. The inhibition of those two key enzymes is also mediated, to a lesser extent, by the activation of FXR in hepatocytes. This latter will induce the transcription of the nuclear receptor small heterodimer partner (SHP) resulting in the inhibition of CYP7A1 and CYP8B1 to avoid BA accumulation, which can induce liver inflammation and injury [18].

- FXR, Energy Homeostasis and Inflammation

FXR actions have extensively been studied and conflicting results were reported regarding its beneficial effects during pathological conditions. Many Fxr knockout animals were generated and several experiments demonstrated that the deletion of $F x r$ was deleterious for the regulation of BA homeostasis as well as lipid and glucose metabolism [51-54]. First, FXR activation has been indicated to prevent the hepatic accumulation of BAs to toxic levels by inducing BSEP and BAAT in order to enhance BA efflux and conjugation, respectively. In addition to inhibiting BA synthesis, FXR stimulation may also lower the reuptake of plasma BA by downregulating NTCP [55-57]. It was also demonstrated that hepatic lipogenesis was decreased upon FXR activation. Indeed, FXR stimulation enhances fatty acid oxidation through peroxisome proliferator-activated receptor (PPAR) $\alpha$ stimulation and reduces de novo lipogenesis by repressing both carbohydrate responsive element binding protein (ChREBP) and indirectly sterol responsive element binding protein 1 (SREBP-1c) [58-61]. More precisely, hepatic FXR activation leads to the activation of SHP which in turn inhibits liver $X$ receptor (LXR) resulting in the repression of SREBP-1c [62]. 
Regarding glucose homeostasis, the role of FXR is less clear. One study showed that FXR stimulation inhibited gluconeogenesis by repressing two rate-limiting step enzymes (i.e., phosphoenolpyruvate carboxykinase (Pck1) and glucose-6-phosphatase (G6pc)) in vitro whereas another study demonstrated the opposite $[63,64]$. In spite of this dissimilarity, most of the experiments performed on mice indicated that FXR activation lowers blood glucose level and enhances insulin sensitivity $[53,54,65]$. Finally, anti-inflammatory properties have also been described upon FXR activation in the liver. Although, the decrease in proinflammatory cytokines is likely due to the transrepression of nuclear factor-kappa $B$ (NF-kB) [66-68], other mechanisms may also occur. For instance, FXR anti-inflammatory effects could also be linked to a reduced hepatic lipid accumulation [61]. Indeed, an elevation of hepatic lipids has been reported to induce ROS formation and to activate NF- $\mathrm{kB}$-related pathways, worsening liver inflammation $[69,70]$. Further studies are thereby required to provide a better understanding of the mechanisms underlying this FXR function.

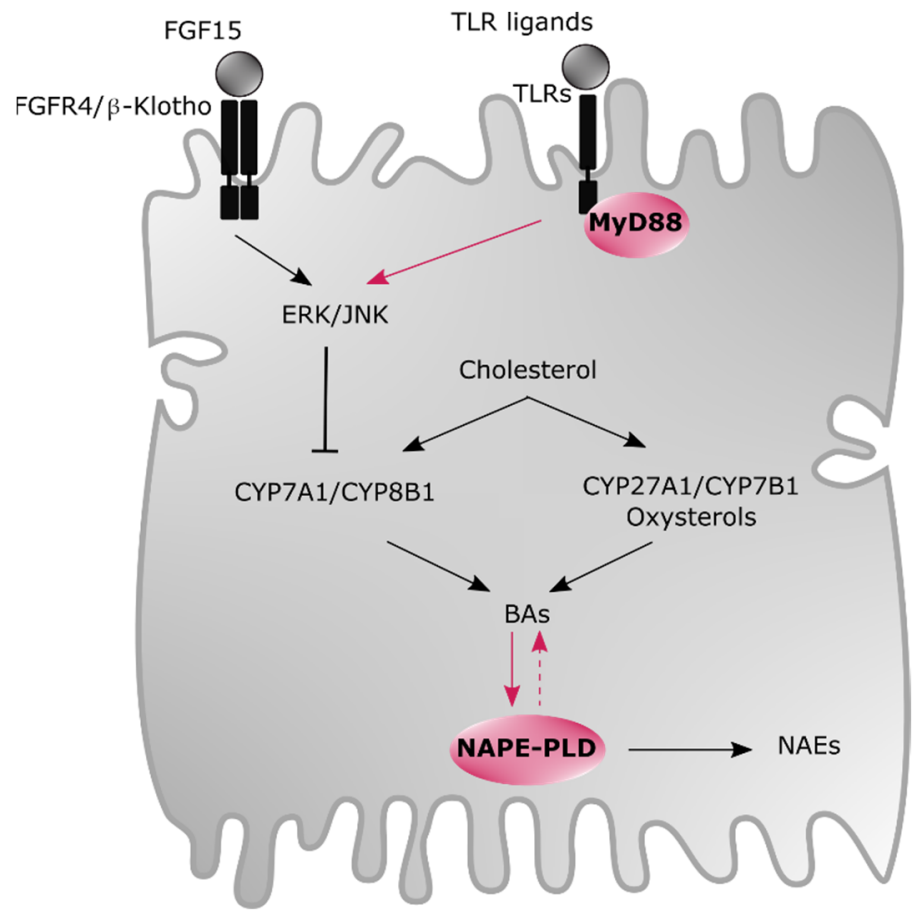

Figure 3. Modulation of oxysterol and BA profiles by the hepatic endocannabinoid and immune system in male mice. BAs are cholesterol-derived bioactive lipids synthesized by two pathways in hepatocytes: the classic pathway (i.e., CYP7A1 and CYP8B1) and the alternative pathway (i.e., CYP27A1 and CYP7B1), this latter being the main route for oxysterol production. BA synthesis is under the regulation of a negative feedback loop. When FGF15, produced by enterocytes and secreted into the portal vein, binds to FGFR4/ $\beta$-Klotho receptor, it induces the repression of BA production by activating ERK/JNK enzymes. Interestingly, this repression cascade seems also under the control of the immune system involving TLR/MyD88 complex. Finally, a reciprocal regulation might take place between BAs and NAPE-PLD, which is responsible for generating other crucial bioactive lipids named NAEs. Abbreviations: BA, bile acid; CYP27A1, sterol 27-hydroxylase; CYP7A1, cholesterol 7 $\alpha$ hydroxylase; CYP7B1, oxysterol $7 \alpha$-hydroxylase; CYP8B1, sterol 12 $\alpha$-hydroxylase; ERK, extracellular signal-regulated kinase; FGF15, fibroblast growth factor 15; FGFR4, fibroblast growth factor receptor 4; JNK, c-Jun N-terminal kinase; MyD88, myeloid differentiation primary response gene 88; NAE, $N$-acylethanolamine; NAPE-PLD, $N$-acylphosphatidylethanolamine-selective phospholipase D; TLR, toll-like receptor.

After having introduced the positive effects of FXR activation, it should be noted that its inactivation can also be beneficial in metabolic diseases [71,72]. For instance, Prawitt and colleagues demonstrated, in mice, that the deletion of $F x r$ conferred a protection 
against insulin resistance as well as obesity induced either genetically or by the diet [71]. Additionally, another study indicated that upon FXR agonist administration, mice fed with a high-fat diet (HFD) gained more weight [73]. In view of all these inconsistencies, researchers went further and succeeded in generating organ-specific FXR knockout mouse models as well as specific (ant)agonists in an effort to assess the tissue-dependent FXR functions. Nonetheless, by genetically disrupting, inhibiting (i.e., glycine- $\beta$-MCA) or enhancing (i.e., fexaramine) only intestinal FXR, here again, paradoxical effects were reported [74-77]. Interestingly, Schmitt and coworkers suggested that hepatic FXR activation would rather be protective since its specific-liver deletion led to an increase in hepatic lipid accumulation under cholesterol diet [78]. Additional studies are clearly warranted to shed light on the beneficial versus deleterious effects of FXR activation in various tissues and different pathological conditions.

\subsubsection{Takeda G-Protein Coupled Receptor 5 (TGR5)}

TGR5 is widely expressed in metabolic relevant tissues such as brown adipose tissue (i.e., adipocytes), pancreas (i.e., $\beta$-cells), intestine (i.e., L-cells and monocytes), muscles (i.e., skeletal and smooth), gallbladder and the liver (i.e., KCs and cholangiocytes) $[79,80]$. Its strongest endogenous agonist includes LCA and, to a lesser extent, (un)conjugated DCA, CDCA, UDCA and CA [81,82]. Interestingly, TGR5 activation promotes health benefits through different mechanisms of action. First, it impacts mitochondrial energy homeostasis by increasing thermogenesis in muscles and adipose tissues [83,84]. Then, it promotes the release of the incretin glucagon-like peptide 1 (GLP-1) in enteroendocrine cells of the gut enhancing insulin secretion $[85,86]$. Finally, it contributes to the reduction of inflammation in both the liver by inhibiting the nuclear translocation of NF-kB in KCs $[87,88]$ and in the intestine in IBD-related context $[80,89]$.

\subsubsection{Vitamin D Receptor (VDR)}

VDR is expressed in various cell types of the immune system (e.g., lymphocytes, neutrophils, macrophages and dendritic cells) and in organs of metabolic relevance including the liver, adipose tissue and intestine [90,91]. This receptor was primary known to be stimulated by the active form of vitamin D (i.e., 1,25-dihydroxyvitamin D3 (1,25(OH)2D3)), and later by LCA [91-93]. Nowadays, it is established that VDR modulates immunity, gut barrier integrity and inflammation $[90,91,93]$. For instance, VDR activation by LCA exerts anti-inflammatory action in colonic cancer cells by repressing NF-kB signaling [94]. This is consistent with the fact that VDR activation by $1,25(\mathrm{OH}) 2 \mathrm{D} 3$ also mediates antiinflammatory properties $[95,96]$. More recently, it has been reported that specific LCAderived molecules (i.e., 3-oxoLCA and isoalloLCA) influence intestinal host immunity through VDR receptor [97,98]. Finally, in 2020, Chatterjee and coworkers explored the impact of the deletion of $V d r$ in intestinal epithelial cells and in myeloid cells, on both the gut microbiota and their associated metabolites. They discovered that these deletions deeply impacted 84 among the 765 metabolites analyzed and sometimes in a gender-dependent manner. For instance, the secondary BAs, LCA and DCA, were found increased in the feces of females deleted for $V d r$ and not in males suggesting that sex hormones might influence BA profile. BA metabolism was further examined and both intestinal and hepatic FXR protein expression were elevated following $V d r$ disruption. This increase was even higher when exposing the mice to HFD [99]. Altogether, these studies highlight the relevance of better understanding the function of VDR especially regarding metabolic and inflammatory diseases.

\subsection{BAs, Gut Microbes and Energy Homeostasis}

In addition to acting as signaling factors, BAs can also modulate host homeostasis directly and indirectly via the gut microbiota (Figure 2B). Indeed, as described earlier in this review, several gut microbes are able to directly convert primary BAs into secondary BAs through the enzymes BSH and $7 \alpha$-dehydroxylase, among others $[20,100]$. Interestingly, 
one resulting metabolites, LCA holds a particular interest in metabolic and inflammatory disorders since it is the more potent agonist ligand of three BA receptors (i.e., TGR5, PXR and VDR) influencing positively the host metabolism [82,92,101-103]. It is thereby not surprising that the reduction of secondary BAs has been associated with health disorders such as chronic intestinal inflammatory diseases (i.e., CD and UC) [31]. This emphasizes another key role of the gut microbiota and eventually the importance of having an appropriate gut ecosystem in pathological situations (for review [83,104]). With this in mind, Allegretti and colleagues conducted a pilot study in which overweight individuals $\left(\mathrm{BMI}>25 \mathrm{~kg} / \mathrm{m}^{2}\right)$ received fecal microbiota transplantation (FMT) from a single lean donor $\left(\mathrm{BMI}=17.5 \mathrm{~kg} / \mathrm{m}^{2}\right)$ by oral capsules during 12 weeks. Although their BMI did not change, they exhibited a "normalized" BA profile strengthening the impact of the gut microbiota on the modulation of BA profile [105]. Finally, recent studies shed light on the fact that some of these microorganisms also participate to the metabolization of cholesterol, which is the precursor of BAs, through specific enzymes [106,107]. Indeed, Kenny and colleagues identified a group of bacterial cholesterol dehydrogenases encoded by ism $A$ genes that convert cholesterol to coprostanol, the latter being mostly excreted in feces [107].

On the other hand, the indirect way includes the modulation of the gut microbiota by BAs. Indeed, these bioactive molecules can alter the maturation, composition and proliferation of these microorganisms, by notably exhibiting antimicrobial properties [108-110]. Therefore, since the gut microbiota is a central actor driving host homeostasis by producing a multitude of metabolites [83], exhibiting a proper BA profile seems crucial to avoid health complications.

Altogether, the existence of this mutual crosstalk is captivating and should receive further attention when exploring host physiology.

\section{Oxysterols in Energy Homeostasis and Inflammation}

\subsection{Oxysterol Profile in Inflammatory and Metabolic Diseases}

Level of oxysterols is altered under pathophysiological conditions such as inflammatory diseases (e.g., IBD), obesity-related disorders (e.g., NAFLD and T2DM) and some cancers [111-118]. Oxysterol measurement from colon biopsies of IBD patients showed that $25-\mathrm{OHC}$ level was higher while $4 \beta-\mathrm{OHC}$ level was lower compared to healthy individuals [118]. Although this field of research is still in its infancy, more data are available regarding metabolic disorders. For instance, a reduction of serum $4 \beta-\mathrm{OHC}$ level has been associated with obesity in humans [111]. Accordingly, this diminution has also been noted in the liver and adipose tissue of both genetically and diet-induced obese mice [112]. Conversely, $4 \beta-\mathrm{OHC}$ as well as $25-\mathrm{OHC}$ and $27-\mathrm{OHC}$ were increased in the blood of NAFLD patients compared to control individuals [116]. Consistent with this finding, hepatic disorders such as cirrhosis were also observed in humans with Cyp $7 b 1$ mutation and were associated with a plasma accumulation of 24(S)-OHC, 25-OHC and 27-OHC [119-121]. Noteworthy, this oxysterol profile might evolve with the disease progression of NAFLD to NASH or might be different according to the samples harvested for oxysterol measurement. Indeed, in a recent study, Raselli and colleagues measured in liver samples, an increased level of 24(S)-OHC and 7-OHC derivatives in NASH patients compared to controls [122]. In line with this, this profile was also identified in the liver of murine model of NASH [122]. Regarding patients with diabetes or hyperlipidemia, a higher 25-OHC, 27-OHC and 7-KC plasma levels were reported compared to healthy controls [114]. Finally, although an excess of some oxysterols is correlated with metabolic disorders, it is worth mentioning that the absence of oxysterols from the alternative pathway also results in devastating health condition. This is the case for humans harboring Cyp27a1 mutation which have an elevated cholesterol level and suffer from cerebrotendineous xanthomatosis $[123,124]$.

\subsection{Oxysterols as Endocrine Molecules}

Oxysterols have been described to exert various effects on host homeostasis through numerous molecular targets including LXR, insulin-induced gene (INSIG) proteins, the 
Epstein-Barr virus-induced gene 2 (EBI2, also known as GPR183), Smoothened (SMO), the retinoid-related orphan receptor (ROR) and the estrogen receptor (ER) $\alpha[9,10,125,126]$. Although the modulation of immunity by oxysterols via ROR, ER or GPR183 is an interesting topic [10,12], in this review, we will focus on their roles in energy homeostasis and inflammation principally via LXR (Figure 2C).

\section{Liver X Receptor (LXR)}

LXR family is involved in the regulation of cholesterol homeostasis, BA synthesis, glucose and lipid metabolism as well as in inflammation [127]. This family includes two isotypes, LXR $\alpha$ and $L X R \beta$, and commonly forms a heterodimer with the retinoid $X$ receptor $(\mathrm{RXR}) \alpha$. LXR $\alpha$ is expressed in metabolically active tissues (e.g., liver, adipose tissue and intestine) whereas LXR $\beta$ is ubiquitously expressed [128]. Noteworthy, it has been discovered that their transcriptional activity was regulated by desmosterol, a precursor of cholesterol, and several oxysterols such as 24(S)-OHC, 25-OHC, 27-OHC and 24(S), 25-epoxycholesterol [125,127].

\section{- $\quad$ LXR and Cholesterol Homeostasis}

It has been largely recognized that oxysterols mediate the elimination of cholesterol excess by activating LXR and by inhibiting SREBP. In response to a low cellular level of cholesterol, SREBP is activated and is responsible of the synthesis and uptake of cholesterol by inducing the transcription of 3-hydroxy-3-methylglutaryl coenzyme A reductase (Hmgcr) and low-density lipoprotein receptor ( $L d l r)$, among others [125,129]. Conversely, when the concentration of cellular cholesterol is high, SREBP is retained in the endoplasmic reticulum (ER) due to the binding of cholesterol/desmosterol and some oxysterols (e.g., 24(S)-OHC, 25-OHC and 27-OHC) on SREBP-cleavage activating protein (SCAP) and INSIG respectively. This action suppresses the synthesis and the uptake of cholesterol. At the same time, oxysterols and desmosterol interact with LXR resulting in the enhancement of the excretion of cholesterol by inducing ATP-binding cassette $(A B C)$ subfamily A member(ABCA) 1 and $A B C$ subfamily $G$ member(ABCG) 1 and in the inhibition of its uptake by stimulating the inducible degrader of the low-density lipoprotein receptor (IDOL) [125]. Moreover, LXR further mediates the elimination of cholesterol excess by inducing the transcription of $A b c g 5 / 8$ and Cyp $7 a 1$ in order to increase its efflux and conversion to BAs, respectively $[130,131]$.

\section{- $\quad$ LXR, Glucose and Lipid Metabolism}

Interestingly, LXR activation by some of its oxysterol agonists (e.g., 22(R)-OHC and 24(S),25-epoxycholesterol) enhances de novo lipogenesis by inducing the expression of notably Srebp1c, fatty acid synthase (Fasn) and stearoyl-CoA desaturase (Scd1) [128,132-134]. In addition, LXR stimulation leads to the inhibition of gluconeogenesis by decreasing the expression of Pck1 and G6pc $[135,136]$. Of interest, a similar reduction has been indicated in murine primary hepatocytes treated with $7 \alpha-\mathrm{OHC}$, but this time, in a ROR-dependent manner [137].

The involvement of LXR in glucose and lipid metabolism has been further confirmed by using a non-endogenous oxysterol (i.e., 22(S)-OHC) which behaves as a LXR antagonist [126]. Indeed, incubation of 22(S)-OHC with human skeletal muscle cells from lean, obese and type 2 diabetic individuals enhanced glucose uptake and decreased lipogenesis as reflected by the reduced gene expression of Fasn and $S c d 1$ in all groups [138]. Noteworthy, the reduction of lipid accumulation and Fasn mRNA expression have also been observed in murine adipocytes treated with 27-OHC [139].

\section{- $\quad$ LXR and Inflammation}

One last LXR function discussed in this review regards its impact on inflammation. LXR stimulation leads to the reduction of the inflammatory response and several mechanisms have been proposed over the past few years. As such it has been suggested that LXR may suppress inflammation through the transrepression of proinflammatory gene 
promoters, the promotion of cholesterol efflux, the alteration of lipid profile resulting in an increase in anti-inflammatory lipid level and through the modification of immune cell phenotype [140]. However, although the influence of cholesterol efflux in decreasing inflammation seems to be consistent across studies, it is worth noting that the transrepression activity has been challenged and that Thomas and colleagues recently discovered a cis-repressive activity linked to LXR [141,142]. More studies are definitely required to decipher the exact molecular action of LXR in suppressing inflammation.

In line with this, Jakobsson and coworkers demonstrated that mice deleted for Lxr were more prone to develop colitis compared to controls and that this intestinal inflammation was diminished upon LXR agonist administration. In addition, they showed that inflamed colon of IBD subjects had lower Lxr mRNA expression level compared to noninflamed colons [143]. Finding the right oxysterol(s) leading to this anti-inflammatory effect may open new therapeutic strategy to treat chronic intestinal inflammatory diseases. Nevertheless, one should keep in mind that activating LXR might also lead to increased lipogenesis and different LXR antagonists are being investigated to tackle NAFLD (e.g., 25-OHC-3S) [144-146]. Therefore, intending to design an intestinal-specific LXR agonist might be interesting in this context.

Finally, it should be mentioned that 25-OHC, which can bind to a wide spectrum of receptors (e.g., $\mathrm{LXR} \alpha, \mathrm{LXR} \beta, \mathrm{GPR} 183, \mathrm{ROR} \alpha$ and ROR $\beta$ ) [147-149], is the most studied oxysterol regarding inflammation. However, its function is still debated since it exhibits both pro- and anti-inflammatory properties $[150,151]$. This complexity is further underscored by a recent study of Guillemot-Legris and colleagues which indicated that 25-OHC administration had no inflammatory effect in the colon of a colitis mouse model. Still, they surprisingly found that $4 \beta-\mathrm{OHC}$ administration worsened the intestinal inflammation of this mouse model supporting a potential new function for this oxysterol [118]. Besides this study, we observed that in two specific mouse models of genetically induced hepatic inflammation, both $25-\mathrm{OHC}$ and $4 \beta-\mathrm{OHC}$, were either strongly affected or unaltered despite a similar liver inflammatory tone [152,153]. Altogether, these data support that further experiments are needed to clarify the exact roles of these two oxysterols in inflammation and eventually the molecular targets of $4 \beta-\mathrm{OHC}$.

To conclude, despite their structural similarities, oxysterols exhibit a broad range of physiological effects and sometimes show opposite actions. It should be emphasized that it is quite difficult to assign a clear function to a specific oxysterol since this system is highly complex. Indeed, one oxysterol can target several receptors and these receptors are not specific to one oxysterol. Moreover, a single enzyme can be involved in the formation of several oxysterols (e.g., CYP27A1 and CYP7B1) and a specific oxysterol can either be generated by different pathways (e.g., 25-OHC) or metabolized through various enzymes (e.g., $7 \alpha-\mathrm{OHC}$ and 27-OHC) [9]. Nonetheless, given their involvement in key signaling pathways associated to inflammatory and metabolic disorders, research on these bioactive lipids should definitely be pushed forward.

\section{Newly Identified Modulators of BAs and Oxysterols}

Although the synthesis and the regulation of both BAs and oxysterols are becoming well described in the literature, we have discovered that disrupting specific genes involved in innate immunity or belonging to the endocannabinoid system, within hepatocytes, was strongly linked with a modulation of both the synthesis and the degradation of BAs and oxysterols (Figure 3) [152,153].

Myeloid differentiation primary response gene 88 (MyD88), a key player of the immune system, has long been considered as only controlling inflammatory signaling cascades. However, its physiological role has evidently been undervalued. More precisely, we previously demonstrated that MyD88 was also able to modulate energy, glucose and lipid metabolism [154]. Recently, we discovered that mice harboring hepatocyte-specific deletion of MyD88 ( $M y d 88^{\Delta H e p}$ ) were predisposed to liver fat accumulation, glucose intolerance and inflammation [155]. By further exploring the molecular mechanisms underlying 
this phenotype, we performed lipidomic analysis and found that $M y d 88^{\Delta H e p}$ mice had an altered BA and oxysterol metabolism [153]. We showed that the absence of MyD88 in hepatocytes impacted the negative feedback loop suppressing BA synthesis likely by a mechanism involving ERK activity. Finally, we observed that the predisposition of these mice to hepatic inflammation was linked to the accumulation of 25-OHC and to a lower extent to $4 \beta-\mathrm{OHC}$ [153]. Altogether, these data revealed an unexpected crosstalk between the innate immune system and liver lipid metabolism and highlighted a new role for hepatocyte MyD88 as a regulator of BA synthesis.

The endocannabinoid system participates to the regulation of several crucial functions in host health such as food intake, energy balance and inflammation [156,157]. Accordingly, alteration of this complex system has been associated with diverse metabolic disorders. Remarkably, among the bioactive lipids involved in this system, modifications of $\mathrm{N}$-acylethanolamine (NAE) levels have been reported. The role of these bioactive lipids are emerging and they are mainly synthesized by $N$-acylphosphatidylethanolamine-selective phospholipase D (NAPE-PLD) [156].

We have previously proven that deleting Napepld in either the intestine or the adipose tissue was correlated with a higher susceptibility to obesity, diabetes and inflammation $[158,159]$. In addition, by generating a new mouse model of inducible Napepld hepatocyte-specific deletion (Napepld ${ }^{\Delta \mathrm{Hep}}$ ), we found that the absence of NAPE-PLD, specifically in hepatocytes, induced an increased fat mass gain and hepatic steatosis in mice and that Napepld ${ }^{\Delta \mathrm{Hep}}$ mice were more sensitive to liver inflammation compared to controls [152]. By seeking for the molecular mechanisms, as expected we found that the majority of the endocannabinoids were affected by the deletion. More surprisingly, by using a lipidomic approach we discovered that Napepld ${ }^{\Delta \text { Hep }}$ mice displayed a distinct profile of both oxysterols and BAs [152]. We thereby identified a novel role for hepatocyte NAPE-PLD which goes beyond the mere synthesis of NAEs. Interestingly, it has been recently demonstrated that BAs also regulate NAPE-PLD activity suggesting the existence of a potential mutual crosstalk between the endocannabinoid system and BA metabolism. As such, DCA $\left(\mathrm{K}_{\mathrm{D}} \sim 43 \mu \mathrm{M}\right)$ and CDCA $\left(\mathrm{K}_{\mathrm{D}} \sim 25 \mu \mathrm{M}\right)$ have been described to stabilize and drive NAPE-PLD catalytic activity whereas LCA $\left(K_{D} \sim 20 \mu \mathrm{M}\right)$, which showed the highest affinity for the enzyme, has been indicated to inhibit its activation [160]. In line with this, in vitro LCA inhibits the enzyme at a low concentration $(\sim 68 \mu \mathrm{M})$ whereas the BA concentration required to activate NAPE-PLD and to induce a half-maximal response varies from $\sim 2$ to $4 \mathrm{mM}$ [160]. Although the physiological meaning of this study remains to be assessed in vivo, these results seem promising since BA concentration spans from $\sim 2$ to $10 \mathrm{mM}$ in the ileum after meal ingestion and at lower range $(\mu \mathrm{M})$ in the blood and the liver $[26,161,162]$. More recently, tauroursodeoxycholic acid (TUDCA), taurohyodeoxycholic acid (THDCA) as well as $\alpha / \beta$-MCAs and their taurine-conjugated forms have also been identified as NAPE-PLD inhibitors, although slightly less potent than LCA [163]. These studies paved the way to the design of specific NAPE-PLD modulators [164].

Even though the exact mechanisms explaining the interconnections observed between either the endocannabinoid or immune system and BAs/oxysterols are still under investigations, these data strongly suggest that any putative dietary intervention or drug treatment targeting the immunity, or the endocannabinoid system might influence BA and/or oxysterol profile, and thus host homeostasis.

\section{Therapeutic Strategies}

Metabolic and inflammatory disorders are still rising among the worldwide population $[165,166]$. Despite huge efforts to slow their progression, the efficacy of the current treatments is still limited emphasizing the need to find new therapeutic approaches $[165,167]$. As BAs are bioactive lipids displaying pleiotropic actions regarding energy homeostasis and inflammation, several strategies have been developed based on their metabolic functions. Although this is not the purpose of this review, we have briefly mentioned the current targets and strategies. 
Due to its pivotal function on host homeostasis, FXR has become an attractive therapeutic target to treat metabolic disorders and many FXR agonists have been designed [168]. Among those, obeticholic acid (OCA), a semi-synthetic BA analogue based on CDCA structure which has already been approved to treat primary biliary cholangitis in humans, showed all the beneficial health effects of FXR activation when administered in animals [66,169-171] and is currently a good candidate for the treatment of NASH and T2DM [16]. From a clinical point of view, administration of OCA in a phase II trial in NAFLD and T2DM patients resulted in an amelioration of insulin sensitivity and a decrease in liver proinflammatory markers [172]. Moreover, in a phase III clinical trial for treating $\mathrm{NASH}$, the administration of $25 \mathrm{mg}$ of OCA on a daily basis during 18 months improved fibrosis in NASH patients [173]. Noteworthy, some safety concerns have been raised regarding this compound such as an increased level of serum LDL cholesterol, decreased level of serum HDL cholesterol, gastrointestinal issues and pruritus. These side effects have delayed its approval on the market and other novel candidates are currently under clinical investigations $[168,174]$.

Aside from FXR, TGR5 is also a potential interesting target. Indeed, many rodent studies showed that TGR 5 activation reduces inflammatory responses and promotes thermogenesis and insulin sensitivity. Hence, this receptor has drawn considerable attention from a therapeutic view [16,79]. Over the past years many selective and dual agonists (i.e., TGR5/FXR) have been developed and tested [86,175-180]. Despite extensive efforts, the majority of these compounds triggered unwanted side effects mainly because TGR5 is widely expressed in the body and has different physiological actions [79]. For instance, TGR5 over-activation caused pruritus, nausea and gallbladder filling in rodent studies [181-183]. Moreover these adverse effects might be due to the fact that these agonists potentially display off-target effects by stimulating other receptors including LXR and PXR $[147,184,185]$ and exhibit detergent-like properties [186]. For all of these reasons, the focus of the current studies has shifted toward the identification of non-steroidal intestinal-selective TGR5 agonists to tackle T2DM even though avoiding the systemic exposure restricts the beneficial effects of TGR5 regarding energy expenditure and inflammation [187-189]. Finally, it should be pinpointed that both clinical studies and evidence of beneficial effects of TGR5 activation in humans are still scarce and required further investigation [79].

In parallel to the design and exploration of receptor activity modulators, FGF19 analogs are currently studied. Based on its ability to both suppress BA synthesis and modulate energy homeostasis, FGF19 has recently emerged as an interesting candidate to treat metabolic disorders [190-192]. However, FGF19 has also been associated with an increased risk of developing cancer $[193,194]$. Consequently, an engineered FGF19 analog, Aldafermin, which does not promote tumorigenesis, has been developed and tested in NASH clinical trial. This molecule shows great potential since in a phase II study comprising 78 patients with $\mathrm{NASH}$, it has been reported that patients receiving daily $1 \mathrm{mg}$ of Aldafermin for 24 weeks had a reduced hepatic lipid content.

Finally, the use of BA sequestrant (e.g., colesevelam and colestimide) or ASBT inhibitors, to limit BA absorption and FXR activation, have been investigated but this strategy may be a doubled-edged sword. It is recognized that BA sequestrant improves glucose metabolism and lowers cholesterol level by enhancing its conversion to BAs in the liver but it might also promote an elevation of plasma triglycerides and hepatic steatosis [23,195,196]. Of interest, although displaying similar effects regarding cholesterol metabolism, ASBT inhibitors only partially restrict the absorption of BAs since free BAs are still able to cross the gut barrier through passive diffusion allowing, at a lesser extent, their endocrine actions [197]. Accordingly, its administration in animal models fed with HFD resulted in an improvement of metabolic parameters regarding hepatic steatosis and insulin sensitivity $[197,198]$. In the future, research should assess its putative therapeutic efficacy in humans with metabolic disorders such as NAFLD or T2DM [199,200]. 


\section{Conclusions and Perspectives}

Overall, the liver is a vital and metabolically complex organ that contributes to the synthesis of a constellation of molecules that take part in the regulation of host homeostasis. As discussed in this review, among the plethora of bioactive compounds endogenously produced, BAs and oxysterols are very intricate bioactive lipids acting through various receptors present in numerous tissues. Their synthesis and degradation are finely tuned and controlled by different mechanisms among which some are still to be discovered. Nevertheless, BAs and to a lesser extent, oxysterols, are currently under investigation in preclinical and clinical studies and both are appearing as emerging therapeutic targets to tackle inflammatory and metabolic disorders.

We do believe that future therapies will successfully reach the market, but we also want to highlight that cautious interpretations are warranted regarding the comparisons between data obtained in mice versus humans. This is obviously the case for all the research performed in medicine, but the very specific profile of BAs observed in mice versus humans and eventually the putative changes in receptor affinity and expression may be additional interfering factors. Finally, besides the considerations of the living organism, gender differences are also very critical confounders when investigating metabolic diseases and BA metabolism.

Ultimately, all data deeply demonstrate the existence of multiple interconnections and redundant pathways between cholesterol metabolism, gut microbiota and host homeostasis. Hence, underlining the importance of considering all these systems when working in the field of metabolism and nutrition.

Author Contributions: Conceptualization, C.L. and P.D.C.; writing—original draft preparation, C.L.; writing - review and editing, C.L. and P.D.C.; supervision, P.D.C.; funding acquisition, P.D.C. All authors have read and agreed to the published version of the manuscript.

Funding: This work was supported by the Fonds de la Recherche Scientifique (FNRS FRFS-WELBIO) under the grants WELBIO-CR-2017C-02 and WELBIO-CR-2019C-02R.

Acknowledgments: P.D.C. is senior research associate from the FRS-FNRS.

Conflicts of Interest: PDC is co-founders of A-Mansia Biotech SA and owner of patents on microbiota and metabolic diseases.

\section{References}

1. Ntambi, J.M. Hepatic de Novo Lipogenesis and Regulation of Metabolism; Springer: Berlin/Heidelberg, Germany, 2015.

2. Sanders, F.W.B.; Griffin, J.L. De novo lipogenesis in the liver in health and disease: More than just a shunting yard for glucose. Biol. Rev. 2016, 91, 452-468. [CrossRef] [PubMed]

3. Malarkey, D.E.; Johnson, K.; Ryan, L.; Boorman, G.; Maronpot, R.R. New Insights into Functional Aspects of Liver Morphology. Toxicol. Pathol. 2005, 33, 27-34. [CrossRef]

4. Kuntz, E.; Kuntz, H.-D. Morphology of the Liver. In Hepatology Textbook and Atlas; Springer International Publishing: Berlin/Heidelberg, Germany, 2008; pp. 15-33.

5. Smedsrød, B.; Pertoft, H.; Gustafson, S.; Laurent, T.C. Scavenger functions of the liver endothelial cell. Biochem. J. 1990, 266, 313-327. [CrossRef] [PubMed]

6. Horst, A.K.; Neumann, K.; Diehl, L.; Tiegs, G. Modulation of liver tolerance by conventional and nonconventional antigenpresenting cells and regulatory immune cells. Cell. Mol. Immunol. 2016, 13, 277-292. [CrossRef] [PubMed]

7. Tsuchida, T.; Friedman, T.T.S.L. Mechanisms of hepatic stellate cell activation. Nat. Rev. Gastroenterol. Hepatol. 2017, 14, 397-411. [CrossRef]

8. Vallim, T.Q.D.A.; Tarling, E.J.; Edwards, P.A. Pleiotropic Roles of Bile Acids in Metabolism. Cell Metab. 2013, 17, 657-669. [CrossRef]

9. Guillemot-Legris, O.; Mutemberezi, V.; Muccioli, G.G. Oxysterols in Metabolic Syndrome: From Bystander Molecules to Bioactive Lipids. Trends Mol. Med. 2016, 22, 594-614. [CrossRef]

10. Willinger, T. Oxysterols in intestinal immunity and inflammation. J. Intern. Med. 2018, 285, 367-380. [CrossRef]

11. Griffiths, W.J.; Abdel-Khalik, J.; Hearn, T.; Yutuc, E.; Morgan, A.H.; Wang, Y. Current trends in oxysterol research. Biochem. Soc. Trans. 2016, 44, 652-658. [CrossRef]

12. Luu, W.; Sharpe, L.J.; Capell-Hattam, I.; Gelissen, I.C.; Brown, A.J. Oxysterols: Old Tale, New Twists. Annu. Rev. Pharmacol. Toxicol. 2016, 56, 447-467. [CrossRef] 
13. Russell, D.W. The Enzymes, Regulation, and Genetics of Bile Acid Synthesis. Annu. Rev. Biochem. 2003, 72, 137-174. [CrossRef] [PubMed]

14. Li, T.; Chiang, J.Y.L. Bile Acid Signaling in Metabolic Disease and Drug Therapy. Pharmacol. Rev. 2014, 66, 948-983. [CrossRef]

15. Wahlström, A.; Sayin, S.I.; Marschall, H.-U.; Bäckhed, F. Intestinal Crosstalk between Bile Acids and Microbiota and Its Impact on Host Metabolism. Cell Metab. 2016, 24, 41-50. [CrossRef] [PubMed]

16. Schaap, F.G.; Trauner, M.; Jansen, P.L.M. Bile acid receptors as targets for drug development. Nat. Rev. Gastroenterol. Hepatol. 2014, 11, 55-67. [CrossRef] [PubMed]

17. Li-Hawkins, J.; Gåfvels, M.; Olin, M.; Lund, E.G.; Andersson, U.; Schuster, G.; Bjorkhem, I.; Russell, D.W.; Eggertsen, G. Cholic acid mediates negative feedback regulation of bile acid synthesis in mice. J. Clin. Investig. 2002, 110, 1191-1200. [CrossRef]

18. Pandak, W.M.; Kakiyama, G. The acidic pathway of bile acid synthesis: Not just an alternative pathway. Liver Res. 2019, 3, 88-98. [CrossRef]

19. Honda, A.; Miyazaki, T.; Iwamoto, J.; Hirayama, T.; Morishita, Y.; Monma, T.; Ueda, H.; Mizuno, S.; Sugiyama, F.; Takahashi, S.; et al. Regulation of bile acid metabolism in mouse models with hydrophobic bile acid composition. J. Lipid Res. 2020, 61, 54-69. [CrossRef]

20. Chiang, J.Y.L.; Ferrell, J.M. Bile acid receptors FXR and TGR5 signaling in fatty liver diseases and therapy. Am. J. Physiol. Liver Physiol. 2020, 318, G554-G573. [CrossRef] [PubMed]

21. Monte, M.J.; Marin, J.J.G.; Antelo, A.; Vazquez-Tato, J. Bile acids: Chemistry, physiology, and pathophysiology. World J. Gastroenterol. 2009, 15, 804-816. [CrossRef] [PubMed]

22. Wang, D.Q.-H.; Tazuma, S.; Cohen, D.E.; Carey, M.C. Feeding natural hydrophilic bile acids inhibits intestinal cholesterol absorption: Studies in the gallstone-susceptible mouse. Am. J. Physiol. Liver Physiol. 2003, 285, G494-G502. [CrossRef]

23. Chávez-Talavera, O.; Tailleux, A.; Lefebvre, P.; Staels, B. Bile Acid Control of Metabolism and Inflammation in Obesity, Type 2 Diabetes, Dyslipidemia, and Nonalcoholic Fatty Liver Disease. Gastroenterology 2017, 152, 1679-1694. [CrossRef]

24. Mouzaki, M.; Wang, A.Y.; Bandsma, R.; Comelli, E.M.; Arendt, B.M.; Zhang, L.; Fung, S.; Fischer, S.E.; McGilvray, I.G.; Allard, J.P. Bile Acids and Dysbiosis in Non-Alcoholic Fatty Liver Disease. PLoS ONE 2016, 11, e0151829. [CrossRef] [PubMed]

25. Ferslew, B.C.; Xie, G.; Johnston, C.K.; Su, M.; Stewart, P.W.; Jia, W.; Brouwer, K.L.R.; Barritt, A.S. Altered Bile Acid Metabolome in Patients with Nonalcoholic Steatohepatitis. Dig. Dis. Sci. 2015, 60, 3318-3328. [CrossRef] [PubMed]

26. Jiao, N.; Baker, S.S.; Chapa-Rodriguez, A.; Liu, W.; Nugent, C.A.; Tsompana, M.; Mastrandrea, L.; Buck, M.J.; Baker, R.D.; Genco, R.J.; et al. Suppressed hepatic bile acid signalling despite elevated production of primary and secondary bile acids in NAFLD. Gut 2018, 67, 1881-1891. [CrossRef] [PubMed]

27. Aranha, M.M.; Cortez-Pinto, H.; Costa, A.; Da Silva, I.B.M.; Camilo, M.E.; De Moura, M.C.; Rodrigues, C.M. Bile acid levels are increased in the liver of patients with steatohepatitis. Eur. J. Gastroenterol. Hepatol. 2008, 20, 519-525. [CrossRef]

28. Caussy, C.; Hsu, C.; Singh, S.; Bassirian, S.; Kolar, J.; Faulkner, C.; Sinha, N.; Bettencourt, R.; Gara, N.; Valasek, M.A.; et al. Serum bile acid patterns are associated with the presence of NAFLD in twins, and dose-dependent changes with increase in fibrosis stage in patients with biopsy-proven NAFLD. Aliment. Pharmacol. Ther. 2019, 49, 183-193. [CrossRef]

29. Puri, P.; Daita, K.; Joyce, A.; Mirshahi, F.; Santhekadur, P.K.; Cazanave, S.; Luketic, V.A.; Siddiqui, M.S.; Boyett, S.; Min, H.; et al. The presence and severity of nonalcoholic steatohepatitis is associated with specific changes in circulating bile acids. Hepatology 2018, 67, 534-548. [CrossRef]

30. Molinaro, A.; Wahlström, A.; Marschall, H.-U. Role of Bile Acids in Metabolic Control. Trends Endocrinol. Metab. 2018, 29 , 31-41. [CrossRef]

31. Lavelle, A.; Sokol, H. Gut microbiota-derived metabolites as key actors in inflammatory bowel disease. Nat. Rev. Gastroenterol. Hepatol. 2020, 17, 223-237. [CrossRef]

32. Duboc, H.; Rajca, S.; Rainteau, D.; Benarous, D.; Maubert, M.-A.; Quervain, E.; Thomas, G.; Barbu, V.; Humbert, L.; Despras, G.; et al. Connecting dysbiosis, bile-acid dysmetabolism and gut inflammation in inflammatory bowel diseases. Gut 2013, 62, 531-539. [CrossRef]

33. Franzosa, E.A.; Sirota-Madi, A.; Avila-Pacheco, J.; Fornelos, N.; Haiser, H.J.; Reinker, S.; Vatanen, T.; Hall, A.B.; Mallick, H.; McIver, L.J.; et al. Gut microbiome structure and metabolic activity in inflammatory bowel disease. Nat. Microbiol. 2019, 4, 293-305. [CrossRef]

34. Matsuoka, K.; Suzuki, M.; Honda, C.; Endo, K.; Moroi, Y. Micellization of conjugated chenodeoxy- and ursodeoxycholates and solubilization of cholesterol into their micelles: Comparison with other four conjugated bile salts species. Chem. Phys. Lipids 2006, 139, 1-10. [CrossRef] [PubMed]

35. Murphy, C.; Parini, P.; Wang, J.; Björkhem, I.; Eggertsen, G.; Gåfvels, M. Cholic acid as key regulator of cholesterol synthesis, intestinal absorption and hepatic storage in mice. Biochim. Biophys. Acta (BBA) Mol. Cell Biol. Lipids 2005, 1735, 167-175. [CrossRef]

36. Zhang, Y.; Jiang, R.; Zheng, X.; Lei, S.; Huang, F.; Xie, G.; Kwee, S.; Yu, H.; Farrar, C.; Sun, B.; et al. Ursodeoxycholic acid accelerates bile acid enterohepatic circulation. Br. J. Pharmacol. 2019, 176, 2848-2863. [CrossRef] [PubMed]

37. Haeusler, R.A.; Astiarraga, B.; Camastra, S.; Accili, D.; Ferrannini, E. Human Insulin Resistance Is Associated With Increased Plasma Levels of 12 -Hydroxylated Bile Acids. Diabetes 2013, 62, 4184-4191. [CrossRef]

38. Wei, M.; Huang, F.; Zhao, L.; Zhang, Y.; Yang, W.; Wang, S.; Li, M.; Han, X.; Ge, K.; Qu, C.; et al. A dysregulated bile acid-gut microbiota axis contributes to obesity susceptibility. EBioMedicine 2020, 55, 102766. [CrossRef] 
39. Biemann, R.; Penner, M.; Borucki, K.; Westphal, S.; Luley, C.; Rönicke, R.; Biemann, K.; Weikert, C.; Lux, A.; Goncharenko, N.; et al. Serum bile acids and GLP-1 decrease following telemetric induced weight loss: Results of a randomized controlled trial. Sci. Rep. 2016, 6, 30173. [CrossRef]

40. Jia, W.; Wei, M.; Rajani, C.; Zheng, X. Targeting the alternative bile acid synthetic pathway for metabolic diseases. Protein Cell 2020, 1-15. [CrossRef]

41. Parks, D.J.; Blanchard, S.G.; Bledsoe, R.K.; Chandra, G.; Consler, T.G.; Kliewer, S.A.; Stimmel, J.B.; Willson, T.M.; Zavacki, A.M.; Moore, D.D.; et al. Bile Acids: Natural Ligands for an Orphan Nuclear Receptor. Science 1999, 284, 1365-1368. [CrossRef] [PubMed]

42. Makishima, M.; Okamoto, A.Y.; Repa, J.J.; Tu, H.; Learned, R.M.; Luk, A.; Hull, M.V.; Lustig, K.D.; Mangelsdorf, D.J.; Shan, B. Identification of a Nuclear Receptor for Bile Acids. Science 1999, 284, 1362-1365. [CrossRef]

43. Vaquero, J.; Monte, M.J.; Dominguez, M.; Muntané, J.; Marin, J.J. Differential activation of the human farnesoid X receptor depends on the pattern of expressed isoforms and the bile acid pool composition. Biochem. Pharmacol. 2013, 86, 926-939. [CrossRef]

44. Kanda, T.; Foucand, L.; Nakamura, Y.; Niot, I.; Besnard, P.; Fujita, M.; Sakai, Y.; Hatakeyama, K.; Ono, T.; Fujii, H. Regulation of expression of human intestinal bile acid-binding protein in Caco-2 cells. Biochem. J. 1998, 330 Pt 1, 261-265. [CrossRef]

45. Song, P.; Rockwell, C.E.; Cui, J.Y.; Klaassen, C.D. Individual bile acids have differential effects on bile acid signaling in mice. Toxicol. Appl. Pharmacol. 2015, 283, 57-64. [CrossRef]

46. Yang, Z.-X.; Shen, W.; Sun, H. Effects of nuclear receptor FXR on the regulation of liver lipid metabolism in patients with non-alcoholic fatty liver disease. Hepatol. Int. 2010, 4, 741-748. [CrossRef] [PubMed]

47. Sayin, S.I.; Wahlström, A.; Felin, J.; Jäntti, S.; Marschall, H.-U.; Bamberg, K.; Angelin, B.; Hyötyläinen, T.; Orešič, M.; Bäckhed, F. Gut Microbiota Regulates Bile Acid Metabolism by Reducing the Levels of Tauro-beta-muricholic Acid, a Naturally Occurring FXR Antagonist. Cell Metab. 2013, 17, 225-235. [CrossRef]

48. Chiang, J.Y.L. Bile acids: Regulation of synthesis. J. Lipid Res. 2009, 50, 1955-1966. [CrossRef] [PubMed]

49. Lin, B.C.; Wang, M.; Blackmore, C.; Desnoyers, L.R. Liver-specific Activities of FGF19 Require Klotho beta. J. Biol. Chem. 2007, 282, 27277-27284. [CrossRef]

50. Kong, B.; Wang, L.; Chiang, J.Y.L.; Zhang, Y.; Klaassen, C.D.; Guo, G.L. Mechanism of tissue-specific farnesoid X receptor in suppressing the expression of genes in bile-acid synthesis in mice. Hepatology 2012, 56, 1034-1043. [CrossRef] [PubMed]

51. Sinal, C.J.; Tohkin, M.; Miyata, M.; Ward, J.M.; Lambert, G.; Gonzalez, F.J. Targeted Disruption of the Nuclear Receptor FXR/BAR Impairs Bile Acid and Lipid Homeostasis. Cell 2000, 102, 731-744. [CrossRef]

52. Kok, T.; Hulzebos, C.V.; Wolters, H.; Havinga, R.; Agellon, L.B.; Stellaard, F.; Shan, B.; Schwarz, M.; Kuipers, F. Enterohepatic Circulation of Bile Salts in Farnesoid X Receptor-deficient Mice. J. Biol. Chem. 2003, 278, 41930-41937. [CrossRef] [PubMed]

53. Zhang, Y.; Lee, F.Y.; Barrera, G.; Lee, H.; Vales, C.; Gonzalez, F.J.; Willson, T.M.; Edwards, P.A. Activation of the nuclear receptor FXR improves hyperglycemia and hyperlipidemia in diabetic mice. Proc. Natl. Acad. Sci. USA 2006, 103, 1006-1011. [CrossRef]

54. Ma, K.; Saha, P.K.; Chan, L.; Moore, D.D. Farnesoid X receptor is essential for normal glucose homeostasis. J. Clin. Investig. 2006, 116, 1102-1109. [CrossRef] [PubMed]

55. Pircher, P.C.; Kitto, J.L.; Petrowski, M.L.; Tangirala, R.K.; Bischoff, E.D.; Schulman, I.G.; Westin, S.K. Farnesoid X Receptor Regulates Bile Acid-Amino Acid Conjugation. J. Biol. Chem. 2003, 278, 27703-27711. [CrossRef] [PubMed]

56. Ananthanarayanan, M.; Balasubramanian, N.; Makishima, M.; Mangelsdorf, D.J.; Suchy, F.J. Human Bile Salt Export Pump Promoter Is Transactivated by the Farnesoid X Receptor/Bile Acid Receptor. J. Biol. Chem. 2001, 276, 28857-28865. [CrossRef]

57. Denson, L.A.; Sturm, E.; Echevarria, W.; Zimmerman, T.L.; Makishima, M.; Mangelsdorf, D.J.; Karpen, S.J. The Orphan Nuclear Receptor, shp, Mediates Bile Acid-Induced Inhibition of the Rat Bile Acid Transporter, ntcp. Gastroenterology 2001, 121, 140-147. [CrossRef]

58. Watanabe, M.; Houten, S.M.; Wang, L.; Moschetta, A.; Mangelsdorf, D.J.; Heyman, R.A.; Moore, D.D.; Auwerx, J. Bile acids lower triglyceride levels via a pathway involving FXR, SHP, and SREBP-1c. J. Clin. Investig. 2004, 113, 1408-1418. [CrossRef]

59. Caron, S.; Samanez, C.H.; Dehondt, H.; Ploton, M.; Briand, O.; Lien, F.; Dorchies, E.; Dumont, J.; Postic, C.; Cariou, B.; et al. Farnesoid X Receptor Inhibits the Transcriptional Activity of Carbohydrate Response Element Binding Protein in Human Hepatocytes. Mol. Cell. Biol. 2013, 33, 2202-2211. [CrossRef] [PubMed]

60. Torra, I.P.; Claudel, T.; Duval, C.; Kosykh, V.; Fruchart, J.-C.; Staels, B. Bile Acids Induce the Expression of the Human Peroxisome Proliferator-Activated Receptor $\alpha$ Gene via Activation of the Farnesoid X Receptor. Mol. Endocrinol. 2003, 17, 259-272. [CrossRef]

61. Massafra, V.; Van Mil, S.W. Farnesoid X receptor: A “homeostat" for hepatic nutrient metabolism. Biochim. Biophys. Acta Mol. Basis Dis. 2018, 1864, 45-59. [CrossRef]

62. Xi, Y.; Li, H. Role of farnesoid X receptor in hepatic steatosis in nonalcoholic fatty liver disease. Biomed. Pharmacother. 2020, 121, 109609. [CrossRef]

63. Yamagata, K.; Daitoku, H.; Shimamoto, Y.; Matsuzaki, H.; Hirota, K.; Ishida, J.; Fukamizu, A. Bile Acids Regulate Gluconeogenic Gene Expression via Small Heterodimer Partner-mediated Repression of Hepatocyte Nuclear Factor 4 and Foxo1. J. Biol. Chem. 2004, 279, 23158-23165. [CrossRef]

64. Stayrook, K.R.; Bramlett, K.S.; Savkur, R.S.; Ficorilli, J.; Cook, T.; Christe, M.E.; Michael, L.F.; Burris, T.P. Regulation of Carbohydrate Metabolism by the Farnesoid X Receptor. Endocrinology 2005, 146, 984-991. [CrossRef] [PubMed] 
65. Cariou, B.; Van Harmelen, K.; Duran-Sandoval, D.; Van Dijk, T.H.; Grefhorst, A.; Abdelkarim, M.; Caron, S.; Torpier, G.; Fruchart, J.-C.; Gonzalez, F.J.; et al. The Farnesoid X Receptor Modulates Adiposity and Peripheral Insulin Sensitivity in Mice. J. Biol. Chem. 2006, 281, 11039-11049. [CrossRef]

66. Wang, Y.-D.; Chen, W.-D.; Wang, M.; Yu, D.; Forman, B.M.; Huang, W. Farnesoid X receptor antagonizes nuclear factor kB in hepatic inflammatory response. Hepatology 2008, 48, 1632-1643. [CrossRef]

67. Mencarelli, A.; Renga, B.; Distrutti, E.; Fiorucci, S. Antiatherosclerotic effect of farnesoid X receptor. Am. J. Physiol. Circ. Physiol. 2009, 296, H272-H281. [CrossRef] [PubMed]

68. Massafra, V.; Pellicciari, R.; Gioiello, A.; Van Mil, S.W. Progress and challenges of selective Farnesoid X Receptor modulation. Pharmacol. Ther. 2018, 191, 162-177. [CrossRef] [PubMed]

69. Furukawa, S.; Fujita, T.; Shimabukuro, M.; Iwaki, M.; Yamada, Y.; Nakajima, Y.; Nakayama, O.; Makishima, M.; Matsuda, M.; Shimomura, I. Increased oxidative stress in obesity and its impact on metabolic syndrome. J. Clin. Investig. 2004, 114, 1752-1761. [CrossRef]

70. Cai, D.; Yuan, M.; Frantz, D.F.; Melendez, P.A.; Hansen, L.; Lee, J.; Shoelson, S.E. Local and systemic insulin resistance resulting from hepatic activation of IKK- $\beta$ and NF-KB. Nat. Med. 2005, 11, 183-190. [CrossRef]

71. Prawitt, J.; Abdelkarim, M.; Stroeve, J.H.M.; Popescu, I.; Duez, H.; Velagapudi, V.R.; Dumont, J.; Bouchaert, E.; Van Dijk, T.H.; Lucas, A.; et al. Farnesoid X Receptor Deficiency Improves Glucose Homeostasis in Mouse Models of Obesity. Diabetes 2011, 60, 1861-1871. [CrossRef]

72. Parséus, A.; Sommer, N.; Sommer, F.; Caesar, R.; Molinaro, A.; Ståhlman, M.; Greiner, T.U.; Perkins, R.; Bäckhed, F. Microbiotainduced obesity requires farnesoid $X$ receptor. Gut 2017, 66, 429-437. [CrossRef]

73. Watanabe, M.; Horai, Y.; Houten, S.M.; Morimoto, K.; Sugizaki, T.; Arita, E.; Mataki, C.; Sato, H.; Tanigawara, Y.; Schoonjans, K.; et al. Lowering Bile Acid Pool Size with a Synthetic Farnesoid X Receptor (FXR) Agonist Induces Obesity and Diabetes through Reduced Energy Expenditure. J. Biol. Chem. 2011, 286, 26913-26920. [CrossRef] [PubMed]

74. Jiang, C.; Xie, C.; Li, F.; Zhang, L.; Nichols, R.G.; Krausz, K.W.; Cai, J.; Qi, Y.; Fang, Z.-Z.; Takahashi, S.; et al. Intestinal farnesoid X receptor signaling promotes nonalcoholic fatty liver disease. J. Clin. Investig. 2015, 125, 386-402. [CrossRef] [PubMed]

75. Jiang, C.; Xie, C.; Lv, Y.; Li, J.; Krausz, K.W.; Shi, J.; Brocker, C.N.; Desai, D.; Amin, S.G.; Bisson, W.H.; et al. Intestine-selective farnesoid $X$ receptor inhibition improves obesity-related metabolic dysfunction. Nat. Commun. 2015, 6, 10166. [CrossRef] [PubMed]

76. Fang, S.; Suh, J.M.; Reilly, S.M.; Yu, E.; Osborn, O.; Lackey, D.; Yoshihara, E.; Perino, A.; Jacinto, S.; Lukasheva, Y.; et al. Intestinal FXR agonism promotes adipose tissue browning and reduces obesity and insulin resistance. Nat. Med. 2015, 21, 159-165. [CrossRef] [PubMed]

77. Pathak, P.; Xie, C.; Nichols, R.G.; Ferrell, J.M.; Boehme, S.; Krausz, K.W.; Patterson, A.D.; Gonzalez, F.J.; Chiang, J.Y.L. Intestine farnesoid $X$ receptor agonist and the gut microbiota activate G-protein bile acid receptor-1 signaling to improve metabolism. Hepatology 2018, 68, 1574-1588. [CrossRef]

78. Schmitt, J.; Kong, B.; Stieger, B.; Tschopp, O.; Schultze, S.M.; Rau, M.; Weber, A.; Muellhaupt, B.; Guo, G.L.; Geier, A. Protective effects of farnesoid $X$ receptor (FXR) on hepatic lipid accumulation are mediated by hepatic FXR and independent of intestinal FGF15 signal. Liver Int. 2015, 35, 1133-1144. [CrossRef]

79. Van Nierop, F.S.; Scheltema, M.J.; Eggink, H.M.; Pols, T.W.; Sonne, D.P.; Knop, F.K.; Soeters, M.R. Clinical relevance of the bile acid receptor TGR5 in metabolism. Lancet Diabetes Endocrinol. 2017, 5, 224-233. [CrossRef]

80. Cipriani, S.; Mencarelli, A.; Chini, M.G.; Distrutti, E.; Renga, B.; Bifulco, G.; Baldelli, F.; Donini, A.; Fiorucci, S. The Bile Acid Receptor GPBAR-1 (TGR5) Modulates Integrity of Intestinal Barrier and Immune Response to Experimental Colitis. PLoS ONE 2011, 6, e25637. [CrossRef]

81. Maruyama, T.; Miyamoto, Y.; Nakamura, T.; Tamai, Y.; Okada, H.; Sugiyama, E.; Nakamura, T.; Itadani, H.; Tanaka, K. Identification of membrane-type receptor for bile acids (M-BAR). Biochem. Biophys. Res. Commun. 2002, 298, 714-719. [CrossRef]

82. Kawamata, Y.; Fujii, R.; Hosoya, M.; Harada, M.; Yoshida, H.; Miwa, M.; Fukusumi, S.; Habata, Y.; Itoh, T.; Shintani, Y.; et al. A G Protein-coupled Receptor Responsive to Bile Acids. J. Biol. Chem. 2003, 278, 9435-9440. [CrossRef]

83. Cani, P.D.; Van Hul, M.; Lefort, C.; Depommier, C.; Rastelli, M.; Everard, A. Microbial regulation of organismal energy homeostasis. Nat. Metab. 2019, 1, 34-46. [CrossRef] [PubMed]

84. Watanabe, M.; Houten, S.M.; Mataki, C.; Christoffolete, M.A.; Kim, B.W.; Sato, H.; Messaddeq, N.; Harney, J.W.; Ezaki, O.; Kodama, T.; et al. Bile acids induce energy expenditure by promoting intracellular thyroid hormone activation. Nat. Cell Biol. 2006, 439, 484-489. [CrossRef]

85. Katsuma, S.; Hirasawa, A.; Tsujimoto, G. Bile acids promote glucagon-like peptide-1 secretion through TGR5 in a murine enteroendocrine cell line STC-1. Biochem. Biophys. Res. Commun. 2005, 329, 386-390. [CrossRef] [PubMed]

86. Thomas, C.; Gioiello, A.; Noriega, L.; Strehle, A.; Oury, J.; Rizzo, G.; Macchiarulo, A.; Yamamoto, H.; Mataki, C.; Pruzanski, M.; et al. TGR5-Mediated Bile Acid Sensing Controls Glucose Homeostasis. Cell Metab. 2009, 10, 167-177. [CrossRef] [PubMed]

87. Pols, T.W.; Nomura, M.; Harach, T.; Sasso, G.L.; Oosterveer, M.H.; Thomas, C.; Rizzo, G.; Gioiello, A.; Adorini, L.; Pellicciari, R.; et al. TGR5 Activation Inhibits Atherosclerosis by Reducing Macrophage Inflammation and Lipid Loading. Cell Metab. 2011, 14, 747-757. [CrossRef] 
88. Wang, Y.-D.; Chen, W.-D.; Yu, D.; Forman, B.M.; Huang, W. The G-Protein-coupled bile acid receptor, Gpbar1 (TGR5), negatively regulates hepatic inflammatory response through antagonizing nuclear factor kappa light-chain enhancer of activated B cells (NF-KB) in mice. Hepatol. 2011, 54, 1421-1432. [CrossRef]

89. Sinha, S.R.; Haileselassie, Y.; Nguyen, L.P.; Tropini, C.; Wang, M.; Becker, L.S.; Sim, D.; Jarr, K.; Spear, E.T.; Singh, G.; et al. Dysbiosis-Induced Secondary Bile Acid Deficiency Promotes Intestinal Inflammation. Cell Host Microbe 2020, 27, 659-670. [CrossRef]

90. Bakke, D.; Chatterjee, I.; Agrawal, A.; Dai, Y.; Sun, A.J. Regulation of Microbiota by Vitamin D Receptor: A Nuclear Weapon in Metabolic Diseases. Nucl. Recept. Res. 2018, 5. [CrossRef]

91. White, J.H. Vitamin D metabolism and signaling in the immune system. Rev. Endocr. Metab. Disord. 2011, 13, 21-29. [CrossRef] [PubMed]

92. Makishima, M.; Lu, T.T.; Xie, W.; Whitfield, G.K.; Domoto, H.; Evans, R.M.; Haussler, M.R.; Mangelsdorf, D.J. Vitamin D Receptor as an Intestinal Bile Acid Sensor. Science 2002, 296, 1313-1316. [CrossRef]

93. White, J.H. Vitamin D deficiency and the pathogenesis of Crohn's disease. J. Steroid Biochem. Mol. Biol. 2018, 175, 23-28. [CrossRef]

94. Sun, J.; Mustafi, R.; Cerda, S.; Chumsangsri, A.; Xia, Y.R.; Li, Y.C.; Bissonnette, M. Lithocholic acid down-regulation of NF-кB activity through vitamin D receptor in colonic cancer cells. J. Steroid Biochem. Mol. Biol. 2008, 111, 37-40. [CrossRef] [PubMed]

95. Gurlek, A.; Pittelkow, M.R.; Kumar, R. Modulation of Growth Factor/Cytokine Synthesis and Signaling by 1 $\alpha, 25-$ Dihydroxyvitamin D3: Implications in Cell Growth and Differentiation. Endocr. Rev. 2002, 23, 763-786. [CrossRef]

96. Yu, X.P.; Bellido, T.; Manolagas, S.C. Down-regulation of NF-kappa B protein levels in activated human lymphocytes by 1,25-dihydroxyvitamin D3. Proc. Natl. Acad. Sci. USA 1995, 92, 10990-10994. [CrossRef]

97. Song, X.; Sun, X.; Oh, S.F.; Wu, M.; Zhang, Y.; Zheng, W.; Geva-Zatorsky, N.; Jupp, R.; Mathis, D.; Benoist, C.; et al. Microbial bile acid metabolites modulate gut ROR $\gamma+$ regulatory T cell homeostasis. Nat. Cell Biol. 2020, 577, 410-415. [CrossRef]

98. Hang, S.; Paik, D.; Yao, L.; Kim, E.; Trinath, J.; Lu, J.; Ha, S.; Nelson, B.N.; Kelly, S.P.; Wu, L.; et al. Bile acid metabolites control TH17 and Treg cell differentiation. Nat. Cell Biol. 2019, 576, 143-148. [CrossRef]

99. Chatterjee, I.; Lu, R.; Zhang, Y.; Zhang, J.; Dai, Y.; Xia, Y.; Sun, J. Vitamin D receptor promotes healthy microbial metabolites and microbiome. Sci. Rep. 2020, 10, 7340. [CrossRef] [PubMed]

100. Jia, W.; Xie, G.; Jia, W. Bile acid-microbiota crosstalk in gastrointestinal inflammation and carcinogenesis. Nat. Rev. Gastroenterol. Hepatol. 2018, 15, 111-128. [CrossRef]

101. Xie, W.; Radominska-Pandya, A.; Shi, Y.; Simon, C.M.; Nelson, M.C.; Ong, E.S.; Waxman, D.J.; Evans, R.M. An essential role for nuclear receptors SXR/PXR in detoxification of cholestatic bile acids. Proc. Natl. Acad. Sci. USA 2001, 98, 3375-3380. [CrossRef] [PubMed]

102. Staudinger, J.L.; Goodwin, B.; Jones, S.A.; Hawkins-Brown, D.; MacKenzie, K.I.; Latour, A.; Liui, Y.; Klaasseni, C.D.; Brown, K.K.; Reinhard, J.; et al. The nuclear receptor PXR is a lithocholic acid sensor that protects against liver toxicity. Proc. Natl. Acad. Sci. USA 2001, 98, 3369-3374. [CrossRef]

103. Sato, H.; Macchiarulo, A.; Thomas, C.; Gioiello, A.; Une, M.; Hofmann, A.F.; Saladin, R.; Schoonjans, K.; Pellicciari, R.; Auwerx, J. Novel Potent and Selective Bile Acid Derivatives as TGR5 Agonists: Biological Screening, Structure-Activity Relationships, and Molecular Modeling Studies. J. Med. Chem. 2008, 51, 1831-1841. [CrossRef]

104. Paone, P.; Cani, P.D. Mucus barrier, mucins and gut microbiota: The expected slimy partners? Gut 2020, 69, 2232-2243. [CrossRef]

105. Allegretti, J.R.; Kassam, Z.; Mullish, B.H.; Chiang, A.; Carrellas, M.; Hurtado, J.; Marchesi, J.R.; McDonald, J.A.; Pechlivanis, A.; Barker, G.F.; et al. Effects of Fecal Microbiota Transplantation with Oral Capsules in Obese Patients. Clin. Gastroenterol. Hepatol. 2020, 18, 855-863. [CrossRef]

106. Gérard, P. Metabolism of Cholesterol and Bile Acids by the Gut Microbiota. Pathogens 2013, 3, 14-24. [CrossRef] [PubMed]

107. Kenny, D.J.; Plichta, D.R.; Shungin, D.; Koppel, N.; Hall, A.B.; Fu, B.; Vasan, R.S.; Shaw, S.Y.; Vlamakis, H.; Balskus, E.P.; et al. Cholesterol Metabolism by Uncultured Human Gut Bacteria Influences Host Cholesterol Level. Cell Host Microbe 2020, 28, 245-257. [CrossRef]

108. Kurdi, P.; Kawanishi, K.; Mizutani, K.; Yokota, A. Mechanism of Growth Inhibition by Free Bile Acids in Lactobacilli and Bifidobacteria. J. Bacteriol. 2006, 188, 1979-1986. [CrossRef] [PubMed]

109. Ridlon, J.M.; Kang, D.J.; Hylemon, P.B.; Bajaj, J.S. Bile acids and the gut microbiome. Curr. Opin. Gastroenterol. 2014, 30, 332-338. [CrossRef]

110. Van Best, N.; Rolle-Kampczyk, U.; Schaap, F.G.; Basic, M.; Damink, S.W.M.O.; Bleich, A.; Savelkoul, P.H.M.; Von Bergen, M.; Penders, J.; Hornef, M.W. Bile acids drive the newborn's gut microbiota maturation. Nat. Commun. 2020, 11, 3692. [CrossRef]

111. Tremblay-Franco, M.; Zerbinati, C.; Pacelli, A.; Palmaccio, G.; Lubrano, C.; Ducheix, S.; Guillou, H.; Iuliano, L. Effect of obesity and metabolic syndrome on plasma oxysterols and fatty acids in human. Steroids 2015, 99, 287-292. [CrossRef]

112. Guillemot-Legris, O.; Mutemberezi, V.; Cani, P.; Muccioli, G.G. Obesity is associated with changes in oxysterol metabolism and levels in mice liver, hypothalamus, adipose tissue and plasma. Sci. Rep. 2016, 6, 19694. [CrossRef] [PubMed]

113. Mutemberezi, V.; Masquelier, J.; Guillemot-Legris, O.; Muccioli, G.G. Development and validation of an HPLC-MS method for the simultaneous quantification of key oxysterols, endocannabinoids, and ceramides: Variations in metabolic syndrome. Anal. Bioanal. Chem. 2015, 408, 733-745. [CrossRef]

114. Murakami, H.; Tamasawa, N.; Matsui, J.; Yasujima, M.; Suda, T. Plasma oxysterols and tocopherol in patients with diabetes mellitus and hyperlipidemia. Lipids 2000, 35, 333-338. [CrossRef] 
115. Bertolotti, M.; Del Puppo, M.; Corna, F.; Anzivino, C.; Gabbi, C.; Baldelli, E.; Carulli, L.; Loria, P.; Kienle, M.G.; Carulli, N. Increased appearance rate of 27-hydroxycholesterol in vivo in hypercholesterolemia: A possible compensatory mechanism. Nutr. Metab. Cardiovasc. Dis. 2012, 22, 823-830. [CrossRef]

116. Ikegami, T.; Hyogo, H.; Honda, A.; Miyazaki, T.; Tokushige, K.; Hashimoto, E.; Inui, K.; Matsuzaki, Y.; Tazuma, S. Increased serum liver $X$ receptor ligand oxysterols in patients with non-alcoholic fatty liver disease. J. Gastroenterol. 2012, 47, $1257-1266$. [CrossRef] [PubMed]

117. Griffiths, W.J.; Wang, Y. Oxysterol research: A brief review. Biochem. Soc. Trans. 2019, 47, 517-526. [CrossRef]

118. Guillemot-Legris, O.; Mutemberezi, V.; Buisseret, B.; Paquot, A.; Palmieri, V.; Bottemanne, P.; Lemaire, J.; Rahier, J.-F.; Alhouayek, M.; Muccioli, G.G. Colitis Alters Oxysterol Metabolism and is Affected by $4 \beta$-Hydroxycholesterol Administration. J. Crohn's Colitis 2018, 13, 218-229. [CrossRef]

119. Setchell, K.D.R.; Schwarz, M.; O'Connell, N.C.; Lund, E.G.; Davis, D.L.; Lathe, R.; Thompson, H.R.; Tyson, R.W.; Sokol, R.J.; Russell, D.W. Identification of a new inborn error in bile acid synthesis: Mutation of the oxysterol 7alpha-hydroxylase gene causes severe neonatal liver disease. J. Clin. Investig. 1998, 102, 1690-1703. [CrossRef] [PubMed]

120. Dai, D.; Mills, P.B.; Footitt, E.; Gissen, P.; McClean, P.; Stahlschmidt, J.; Coupry, I.; Lavie, J.; Mochel, F.; Goizet, C.; et al. Liver disease in infancy caused by oxysterol $7 \alpha$-hydroxylase deficiency: Successful treatment with chenodeoxycholic acid. J. Inherit. Metab. Dis. 2014, 37, 851-861. [CrossRef]

121. Ueki, I.; Kimura, A.; Nishiyori, A.; Chen, H.-L.; Takei, H.; Nittono, H.; Kurosawa, T. Neonatal Cholestatic Liver Disease in an Asian Patient with a Homozygous Mutation in the Oxysterol $7 \alpha$-hydroxylase Gene. J. Pediatr. Gastroenterol. Nutr. 2008, 46, 465-469. [CrossRef] [PubMed]

122. Raselli, T.; Hearn, T.; Wyss, A.; Atrott, K.; Peter, A.; Frey-Wagner, I.; Spalinger, M.R.; Maggio, E.M.; Sailer, A.W.; Schmitt, J.; et al. Elevated oxysterol levels in human and mouse livers reflect nonalcoholic steatohepatitis. J. Lipid Res. 2019, 60, 1270-1283. [CrossRef]

123. Javitt, N. 26-Hydroxycholesterol: Synthesis, metabolism, and biologic activities. J. Lipid Res. 1990, 31, 1527-1533. [CrossRef]

124. Salen, G.; Grundy, S.M. The Metabolism of Cholestanol, Cholesterol, and Bile Acids in Cerebrotendinous Xanthomatosis. J. Clin. Investig. 1973, 52, 2822-2835. [CrossRef]

125. Spann, N.J.; Glass, C.K. Sterols and oxysterols in immune cell function. Nat. Immunol. 2013, 14, 893-900. [CrossRef] [PubMed]

126. Mutemberezi, V.; Guillemot-Legris, O.; Muccioli, G.G. Oxysterols: From cholesterol metabolites to key mediators. Prog. Lipid Res. 2016, 64, 152-169. [CrossRef] [PubMed]

127. Wang, B.; Tontonoz, P. Liver X receptors in lipid signalling and membrane homeostasis. Nat. Rev. Endocrinol. 2018, 14, $452-463$. [CrossRef]

128. Hong, C.; Tontonoz, P. Liver X receptors in lipid metabolism: Opportunities for drug discovery. Nat. Rev. Drug Discov. 2014, 13, 433-444. [CrossRef]

129. Goldstein, J.L.; Brown, M.S. The LDL Receptor. Arter. Thromb. Vasc. Biol. 2009, 29, 431-438. [CrossRef] [PubMed]

130. Wang, J.; Mitsche, M.A.; Lütjohann, D.; Cohen, J.C.; Xie, X.-S.; Hobbs, H.H. Relative roles of ABCG5/ABCG8 in liver and intestine. J. Lipid Res. 2015, 56, 319-330. [CrossRef]

131. Peet, D.J.; Turley, S.D.; Ma, W.; Janowski, B.A.; Lobaccaro, J.-M.A.; Hammer, R.E.; Mangelsdorf, D.J. Cholesterol and Bile Acid Metabolism Are Impaired in Mice Lacking the Nuclear Oxysterol Receptor LXR $\alpha$. Cell 1998, 93, 693-704. [CrossRef]

132. Chu, K.; Miyazaki, M.; Man, W.C.; Ntambi, J.M. Stearoyl-Coenzyme A Desaturase 1 Deficiency Protects against Hypertriglyceridemia and Increases Plasma High-Density Lipoprotein Cholesterol Induced by Liver X Receptor Activation. Mol. Cell. Biol. 2006, 26, 6786-6798. [CrossRef]

133. Joseph, S.B.; Laffitte, B.A.; Patel, P.H.; Watson, M.A.; Matsukuma, K.E.; Walczak, R.; Collins, J.L.; Osborne, T.F.; Tontonoz, P. Direct and Indirect Mechanisms for Regulation of Fatty Acid Synthase Gene Expression by Liver X Receptors. J. Biol. Chem. 2002, 277, 11019-11025. [CrossRef]

134. Yoshikawa, T.; Shimano, H.; Amemiya-Kudo, M.; Yahagi, N.; Hasty, A.H.; Matsuzaka, T.; Okazaki, H.; Tamura, Y.; Iizuka, Y.; Ohashi, K.; et al. Identification of Liver X Receptor-Retinoid X Receptor as an Activator of the Sterol Regulatory Element-Binding Protein 1c Gene Promoter. Mol. Cell. Biol. 2001, 21, 2991-3000. [CrossRef] [PubMed]

135. Jakobsson, T.; Treuter, E.; Gustafsson, J.A.; Steffensen, K.R. Liver X receptor biology and pharmacology: New pathways, challenges and opportunities. Trends Pharmacol. Sci. 2012, 33, 394-404. [CrossRef]

136. Patel, R.; Patel, M.; Tsai, R.; Lin, V.; Bookout, A.L.; Zhang, Y.; Magomedova, L.; Li, T.; Chan, J.F.; Budd, C.; et al. LXR $\beta$ is required for glucocorticoid-induced hyperglycemia and hepatosteatosis in mice. J. Clin. Investig. 2011, 121, 431-441. [CrossRef]

137. Wang, Y.; Kumar, N.; Solt, L.A.; Richardson, T.I.; Helvering, L.M.; Crumbley, C.; Garcia-Ordonez, R.D.; Stayrook, K.R.; Zhang, X.; Novick, S.; et al. Modulation of Retinoic Acid Receptor-related Orphan Receptor $\alpha$ and $\gamma$ Activity by 7-Oxygenated Sterol Ligands. J. Biol. Chem. 2010, 285, 5013-5025. [CrossRef] [PubMed]

138. Kase, E.T.; Thoresen, G.H.; Westerlund, S.; Højlund, K.; Rustan, A.C.; Gaster, M. Liver X receptor antagonist reduces lipid formation and increases glucose metabolism in myotubes from lean, obese and type 2 diabetic individuals. Diabetologia 2007, 50, 2171-2180. [CrossRef]

139. Shirouchi, B.; Kashima, K.; Horiuchi, Y.; Nakamura, Y.; Fujimoto, Y.; Tong, L.-T.; Sato, M. 27-Hydroxycholesterol suppresses lipid accumulation by down-regulating lipogenic and adipogenic gene expression in 3T3-L1 cells. Cytotechnology 2016, 69, 485-492. [CrossRef] 
140. Schulman, I.G. Liver X receptors link lipid metabolism and inflammation. FEBS Lett. 2017, 591, 2978-2991. [CrossRef]

141. Medzhitov, R.; Hong, C.; Rong, X.; Zhu, X.; Tarling, E.J.; Hedde, P.N.; Gratton, E.; Parks, J.S.; Tontonoz, P. LXRs link metabolism to inflammation through Abca1-dependent regulation of membrane composition and TLR signaling. Elife 2015, 4, e08009. [CrossRef]

142. Thomas, D.G.; Doran, A.C.; Fotakis, P.; Westerterp, M.; Antonson, P.; Jiang, H.; Jiang, X.-C.; Gustafsson, J.-Å.; Tabas, I.; Tall, A.R. LXR Suppresses Inflammatory Gene Expression and Neutrophil Migration through cis-Repression and Cholesterol Efflux. Cell Rep. 2018, 25, 3774-3785. [CrossRef]

143. Jakobsson, T.; Vedin, L.-L.; Hassan, T.; Venteclef, N.; Greco, D.; D'Amato, M.; Treuter, E.; Gustafsson, J.A.; Steffensen, K.R. The oxysterol receptor LXR $\beta$ protects against DSS- and TNBS-induced colitis in mice. Mucosal Immunol. 2014, 7, 1416-1428. [CrossRef] [PubMed]

144. Bai, Q.; Zhang, X.; Xu, L.; Kakiyama, G.; Heuman, D.M.; Sanyal, A.J.; Pandak, W.M.; Yin, L.; Xie, W.; Ren, S. Oxysterol sulfation by cytosolic sulfotransferase suppresses liver $X$ receptor/sterol regulatory element binding protein-1c signaling pathway and reduces serum and hepatic lipids in mouse models of nonalcoholic fatty liver disease. Metabolism 2012, 61, 836-845. [CrossRef]

145. Xu, L.; Kim, J.K.; Bai, Q.; Zhang, X.; Kakiyama, G.; Min, H.-K.; Sanyal, A.J.; Pandak, W.M.; Ren, S. 5-Cholesten-3ß,25-Diol 3-Sulfate Decreases Lipid Accumulation in Diet-Induced Nonalcoholic Fatty Liver Disease Mouse Model. Mol. Pharmacol. 2012, 83, 648-658. [CrossRef] [PubMed]

146. Ren, S.; Li, X.; Rodriguez-Agudo, D.; Gil, G.; Hylemon, P.; Pandak, W.M. Sulfated oxysterol, 25HC3S, is a potent regulator of lipid metabolism in human hepatocytes. Biochem. Biophys. Res. Commun. 2007, 360, 802-808. [CrossRef]

147. Janowski, B.A.; Grogan, M.J.; Jones, S.A.; Wisely, G.B.; Kliewer, S.A.; Corey, E.J.; Mangelsdorf, D.J. Structural requirements of ligands for the oxysterol liver X receptors LXR and LXR. Proc. Natl. Acad. Sci. USA 1999, 96, 266-271. [CrossRef] [PubMed]

148. Hannedouche, S.; Zhang, J.; Yi, T.; Shen, W.; Nguyen, D.; Pereira, J.P.; Guerini, D.; Baumgarten, B.U.; Roggo, S.; Wen, B.; et al. Oxysterols direct immune cell migration via EBI2. Nat. Cell Biol. 2011, 475, 524-527. [CrossRef]

149. Soroosh, P.; Wu, J.; Xue, X.; Song, J.; Sutton, S.W.; Sablad, M.; Yu, J.; Nelen, M.I.; Liu, X.; Castro, G.; et al. Oxysterols are agonist ligands of ROR $t$ and drive Th17 cell differentiation. Proc. Natl. Acad. Sci. USA 2014, 111, 12163-12168. [CrossRef]

150. Cyster, J.G.; Dang, E.V.; Reboldi, A.; Yi, T. 25-Hydroxycholesterols in innate and adaptive immunity. Nat. Rev. Immunol. 2014, 14, 731-743. [CrossRef]

151. Jang, J.; Park, S.; Hur, H.J.; Cho, H.-J.; Hwang, I.; Kang, Y.P.; Im, I.; Lee, H.; Lee, E.; Yang, W.; et al. 25-hydroxycholesterol contributes to cerebral inflammation of X-linked adrenoleukodystrophy through activation of the NLRP3 inflammasome. Nat. Commun. 2016, 7, 13129. [CrossRef]

152. Lefort, C.; Roumain, M.; Van Hul, M.; Rastelli, M.; Manco, R.; Leclercq, I.; Delzenne, N.M.; Di Marzo, V.; Flamand, N.; Luquet, S.; et al. Hepatic NAPE-PLD Is a Key Regulator of Liver Lipid Metabolism. Cells 2020, 9, 1247. [CrossRef] [PubMed]

153. Lefort, C.; Van Hul, M.; Delzenne, N.M.; Everard, A.; Cani, P.D. Hepatic MyD88 regulates liver inflammation by altering synthesis of oxysterols. Am. J. Physiol. Metab. 2019, 317, E99-E108. [CrossRef] [PubMed]

154. Everard, A.; Geurts, L.; Caesar, R.; Van Hul, M.; Matamoros, S.; Duparc, T.; Denis, R.G.P.; Cochez, P.; Pierard, F.; Castel, J.; et al Intestinal epithelial MyD88 is a sensor switching host metabolism towards obesity according to nutritional status. Nat. Commun. 2014, 5, 5648. [CrossRef] [PubMed]

155. Duparc, T.; Plovier, H.; Marrachelli, V.G.; Van Hul, M.; Essaghir, A.; Ståhlman, M.; Matamoros, S.; Geurts, L.; Pardo-Tendero, M.M.; Druart, C.; et al. Hepatocyte MyD88 affects bile acids, gut microbiota and metabolome contributing to regulate glucose and lipid metabolism. Gut 2016, 66, 620-632. [CrossRef] [PubMed]

156. Di Marzo, V. New approaches and challenges to targeting the endocannabinoid system. Nat. Rev. Drug Discov. 2018, 17, 623-639. [CrossRef]

157. Cani, P.; Plovier, H.; Van Hul, M.; Geurts, L.; Delzenne, N.M.; Druart, C.; Everard, A. Endocannabinoids — at the crossroads between the gut microbiota and host metabolism. Nat. Rev. Endocrinol. 2016, 12, 133-143. [CrossRef] [PubMed]

158. Everard, A.; Plovier, H.; Rastelli, M.; Van Hul, M.; D’Oplinter, A.D.W.; Geurts, L.; Druart, C.; Robine, S.; Delzenne, N.M.; Muccioli, G.G.; et al. Intestinal epithelial N-acylphosphatidylethanolamine phospholipase D links dietary fat to metabolic adaptations in obesity and steatosis. Nat. Commun. 2019, 10, 457. [CrossRef] [PubMed]

159. Geurts, L.; Everard, A.; Van Hul, M.; Essaghir, A.; Duparc, T.; Matamoros, S.; Plovier, H.; Castel, J.; Denis, R.G.P.; Bergiers, M.; et al. Adipose tissue NAPE-PLD controls fat mass development by altering the browning process and gut microbiota. Nat. Commun. 2015, 6, 6495. [CrossRef]

160. Margheritis, E.; Castellani, B.; Magotti, P.; Peruzzi, S.; Romeo, E.; Natali, F.; Mostarda, S.; Gioiello, A.; Piomelli, D.; Garau, G. Bile Acid Recognition by NAPE-PLD. ACS Chem. Biol. 2016, 11, 2908-2914. [CrossRef]

161. Setchell, K.D.; Rodrigues, C.M.; Clerici, C.; Solinas, A.; Morelli, A.; Gartung, C.; Boyer, J. Bile acid concentrations in human and rat liver tissue and in hepatocyte nuclei. Gastroenterology 1997, 112, 226-235. [CrossRef]

162. Northfield, T.C.; McColl, I. Postprandial concentrations of free and conjugated bile acids down the length of the normal human small intestine. Gut 1973, 14, 513-518. [CrossRef]

163. Aggarwal, G.; Zarrow, J.E.; Mashhadi, Z.; Flynn, C.R.; Vinson, P.; Weaver, C.D.; Davies, S.S. Symmetrically substituted dichlorophenes inhibit N-acyl-phosphatidylethanolamine phospholipase D. J. Biol. Chem. 2020, 295, 7289-7300. [CrossRef]

164. Castellani, B.; Diamanti, E.; Pizzirani, D.; Tardia, P.; Maccesi, M.; Realini, N.; Magotti, P.; Garau, G.; Bakkum, T.; Rivara, S.; et al. Synthesis and characterization of the first inhibitor ofN-acylphosphatidylethanolamine phospholipase D (NAPE-PLD). Chem. Commun. 2017, 53, 12814-12817. [CrossRef] 
165. González-Muniesa, P.; Mártinez-González, M.-A.; Hu, F.B.; Després, J.-P.; Matsuzawa, Y.; Loos, R.J.F.; Moreno, L.A.; Bray, G.A.; Martinez, J.A. Obesity. Nat. Rev. Dis. Prim. 2017, 3, 17034. [CrossRef] [PubMed]

166. Kaplan, G.G.; Ng, S.C. Understanding and Preventing the Global Increase of Inflammatory Bowel Disease. Gastroenterology 2017, 152, 313-321. [CrossRef]

167. Jackson, V.M.; Breen, D.M.; Fortin, J.-P.; Liou, A.; Kuzmiski, J.B.; Loomis, A.K.; Rives, M.-L.; Shah, B.; Carpino, P.A. Latest approaches for the treatment of obesity. Expert Opin. Drug Discov. 2015, 10, 825-839. [CrossRef]

168. Han, C.Y. Update on FXR Biology: Promising Therapeutic Target? Int. J. Mol. Sci. 2018, 19, 2069. [CrossRef] [PubMed]

169. Adorini, L.; Pruzanski, M.; Shapiro, D. Farnesoid X receptor targeting to treat nonalcoholic steatohepatitis. Drug Discov. Today 2012, 17, 988-997. [CrossRef] [PubMed]

170. Cipriani, S.; Mencarelli, A.; Palladino, G.; Fiorucci, S. FXR activation reverses insulin resistance and lipid abnormalities and protects against liver steatosis in Zucker (fa/fa) obese rats. J. Lipid Res. 2010, 51, 771-784. [CrossRef]

171. Roberts, S.B.; Ismail, M.; Kanagalingam, G.; Mason, A.L.; Swain, M.G.; Vincent, C.; Yoshida, E.M.; Tsien, C.; Flemming, J.A.; Janssen, H.L.; et al. Real-World Effectiveness of Obeticholic Acid in Patients with Primary Biliary Cholangitis. Hepatol. Commun. 2020, 4, 1332-1345. [CrossRef]

172. Mudaliar, S.; Henry, R.R.; Sanyal, A.J.; Morrow, L.; Marschall, H.; Kipnes, M.; Adorini, L.; Sciacca, C.I.; Clopton, P.; Castelloe, E.; et al. Efficacy and Safety of the Farnesoid X Receptor Agonist Obeticholic Acid in Patients With Type 2 Diabetes and Nonalcoholic Fatty Liver Disease. Gastroenterology 2013, 145, 574-582. [CrossRef]

173. Hindson, J. Obeticholic acid for the treatment of NASH. Nat. Rev. Gastroenterol. Hepatol. 2020, 17, 66. [CrossRef]

174. Pencek, R.; Marmon, T.; Roth, J.D.; Liberman, A.; Hooshmand-Rad, R.; Young, M.A. Effects of obeticholic acid on lipoprotein metabolism in healthy volunteers. Diabetes Obes. Metab. 2016, 18, 936-940. [CrossRef] [PubMed]

175. Rizzo, G.; Passeri, D.; De Franco, F.; Ciaccioli, G.; Donadio, L.; Rizzo, G.; Orlandi, S.; Sadeghpour, B.; Wang, X.X.; Jiang, T.; et al. Functional Characterization of the Semisynthetic Bile Acid Derivative INT-767, a Dual Farnesoid X Receptor and TGR5 Agonist. Mol. Pharmacol. 2010, 78, 617-630. [CrossRef]

176. D’Amore, C.; Di Leva, F.S.; Sepe, V.; Renga, B.; Del Gaudio, C.; D’Auria, M.V.; Zampella, A.; Fiorucci, S.; Limongelli, V. Design, Synthesis, and Biological Evaluation of Potent Dual Agonists of Nuclear and Membrane Bile Acid Receptors. J. Med. Chem. 2014, 57, 937-954. [CrossRef]

177. Carino, A.; Cipriani, S.; Marchianò, S.; Biagioli, M.; Santorelli, C.; Donini, A.; Zampella, A.; Monti, M.C.; Fiorucci, S. BAR502, a dual FXR and GPBAR1 agonist, promotes browning of white adipose tissue and reverses liver steatosis and fibrosis. Sci. Rep. 2017, 7, 42801. [CrossRef] [PubMed]

178. Pellicciari, R.; Gioiello, A.; Macchiarulo, A.; Thomas, C.; Rosatelli, E.; Natalini, B.; Sardella, R.; Pruzanski, M.; Roda, A.; Pastorini, E.; et al. Discovery of $6 \alpha$-Ethyl-23(S)-methylcholic Acid (S-EMCA, INT-777) as a Potent and Selective Agonist for the TGR5 Receptor, a Novel Target for Diabesity. J. Med. Chem. 2009, 52, 7958-7961. [CrossRef] [PubMed]

179. Sepe, V.; Renga, B.; Festa, C.; D’Amore, C.; Masullo, D.; Cipriani, S.; Di Leva, F.S.; Monti, M.C.; Novellino, E.; Limongelli, V.; et al. Modification on Ursodeoxycholic Acid (UDCA) Scaffold. Discovery of Bile Acid Derivatives As Selective Agonists of Cell-Surface G-Protein Coupled Bile Acid Receptor 1 (GP-BAR1). J. Med. Chem. 2014, 57, 7687-7701. [CrossRef]

180. Di Leva, F.S.; Festa, C.; Renga, B.; Sepe, V.; Novellino, E.; Fiorucci, S.; Zampella, A.; Limongelli, V. Structure-based drug design targeting the cell membrane receptor GPBAR1: Exploiting the bile acid scaffold towards selective agonism. Sci. Rep. 2015, 5, 16605. [CrossRef] [PubMed]

181. Alemi, F.; Kwon, E.; Poole, D.P.; Lieu, T.; Lyo, V.; Cattaruzza, F.; Cevikbas, F.; Steinhoff, M.; Nassini, R.; Materazzi, S.; et al. The TGR5 receptor mediates bile acid-induced itch and analgesia. J. Clin. Investig. 2013, 123, 1513-1530. [CrossRef] [PubMed]

182. Briere, D.A.; Ruan, X.; Cheng, C.C.; Siesky, A.M.; Fitch, T.E.; Dominguez, C.; Sanfeliciano, S.G.; Montero, C.; Suen, C.S.; Xu, Y.; et al. Novel Small Molecule Agonist of TGR5 Possesses Anti-Diabetic Effects but Causes Gallbladder Filling in Mice. PLoS ONE 2015, 10, e0136873. [CrossRef]

183. Li, T.; Holmstrom, S.R.; Kir, S.; Umetani, M.; Schmidt, D.R.; Kliewer, S.A.; Mangelsdorf, D.J. The G Protein-Coupled Bile Acid Receptor, TGR5, Stimulates Gallbladder Filling. Mol. Endocrinol. 2011, 25, 1066-1071. [CrossRef]

184. Lehmann, J.M.; McKee, D.D.; Watson, M.A.; Willson, T.M.; Moore, J.T.; Kliewer, S.A. The human orphan nuclear receptor PXR is activated by compounds that regulate CYP3A4 gene expression and cause drug interactions. J. Clin. Investig. 1998, 102, 1016-1023. [CrossRef] [PubMed]

185. Janowski, B.A.; Willy, P.J.; Devi, T.R.; Falck, J.R.; Mangelsdorf, D.J. An oxysterol signalling pathway mediated by the nuclear receptor LXR $\alpha$. Nat. Cell Biol. 1996, 383, 728-731. [CrossRef] [PubMed]

186. Xu, Y. Recent Progress on Bile Acid Receptor Modulators for Treatment of Metabolic Diseases. J. Med. Chem. 2016, 59, 6553-6579. [CrossRef]

187. Di Leva, F.S.; Festa, C.; Carino, A.; De Marino, S.; Marchianò, S.; Di Marino, D.; Finamore, C.; Monti, M.C.; Zampella, A.; Fiorucci, S.; et al. Discovery of ((1,2,4-oxadiazol-5-yl)pyrrolidin-3-yl)ureidyl derivatives as selective non-steroidal agonists of the G-protein coupled bile acid receptor-1. Sci. Rep. 2019, 9, 2504. [CrossRef] [PubMed]

188. Cao, H.; Chen, Z.-X.; Wang, K.; Ning, M.-M.; Zou, Q.-A.; Feng, Y.; Ye, Y.-L.; Leng, Y.; Shen, J.-H. Intestinally-targeted TGR5 agonists equipped with quaternary ammonium have an improved hypoglycemic effect and reduced gallbladder filling effect. Sci. Rep. 2016, 6, 28676. [CrossRef] 
189. LaSalle, M.; Hoguet, V.; Hennuyer, N.; Leroux, F.; Piveteau, C.; Belloy, L.; Lestavel, S.; Vallez, E.; Dorchies, E.; Duplan, I.; et al. Topical Intestinal Aminoimidazole Agonists of G-Protein-Coupled Bile Acid Receptor 1 Promote Glucagon Like Peptide-1 Secretion and Improve Glucose Tolerance. J. Med. Chem. 2017, 60, 4185-4211. [CrossRef]

190. Alvarez-Sola, G.; Uriarte, I.; Latasa, M.U.; Fernandez-Barrena, M.G.; Urtasun, R.; Elizalde, M.; Barcena-Varela, M.; Jiménez, M.; Chang, H.C.; Barbero, R.; et al. Fibroblast growth factor 15/19 (FGF15/19) protects from diet-induced hepatic steatosis: Development of an FGF19-based chimeric molecule to promote fatty liver regeneration. Gut 2017, 66, 1818-1828. [CrossRef] [PubMed]

191. Benoit, B.; Meugnier, E.; Castelli, M.; Chanon, S.; Vieille-Marchiset, A.; Durand, C.; Bendridi, N.; Pesenti, S.; Monternier, P.-A.; Durieux, A.-C.; et al. Fibroblast growth factor 19 regulates skeletal muscle mass and ameliorates muscle wasting in mice. Nat. Med. 2017, 23, 990-996. [CrossRef]

192. Degirolamo, C.; Sabbà, C.; Moschetta, A. Therapeutic potential of the endocrine fibroblast growth factors FGF19, FGF21 and FGF23. Nat. Rev. Drug Discov. 2016, 15, 51-69. [CrossRef]

193. Zucman-Rossi, J.; Villanueva, A.; Nault, J.-C.; Llovet, J.M. Genetic Landscape and Biomarkers of Hepatocellular Carcinoma. Gastroenterology 2015, 149, 1226-1239. [CrossRef]

194. Miura, S.; Mitsuhashi, N.; Shimizu, H.; Kimura, F.; Yoshidome, H.; Otsuka, M.; Kato, A.; Shida, T.; Okamura, D.; Miyazaki, M. Fibroblast growth factor 19 expression correlates with tumor progression and poorer prognosis of hepatocellular carcinoma. $B M C$ Cancer 2012, 12, 56. [CrossRef] [PubMed]

195. Hansen, M.; Sonne, D.P.; Mikkelsen, K.H.; Gluud, L.L.; Vilsbøll, T.; Knop, F.K. Bile acid sequestrants for glycemic control in patients with type 2 diabetes: A systematic review with meta-analysis of randomized controlled trials. J. Diabetes Complicat. 2017, 31, 918-927. [CrossRef]

196. Fonseca, V.A.; Handelsman, Y.; Staels, B. Colesevelam lowers glucose and lipid levels in type 2 diabetes: The clinical evidence. Diabetes Obes. Metab. 2010, 12, 384-392. [CrossRef]

197. Rao, A.; Kosters, A.; Mells, J.E.; Zhang, W.; Setchell, K.D.R.; Amanso, A.M.; Wynn, G.M.; Xu, T.; Keller, B.T.; Yin, H.; et al. Inhibition of ileal bile acid uptake protects against nonalcoholic fatty liver disease in high-fat diet-fed mice. Sci. Transl. Med. 2016, 8, 357ra122. [CrossRef]

198. Ge, M.-X.; Niu, W.-X.; Ren, J.-F.; Cai, S.-Y.; Yu, D.-K.; Liu, H.-T.; Zhang, N.; Zhang, Y.-X.; Wang, Y.-C.; Shao, R.-G.; et al. A novel ASBT inhibitor, IMB17-15, repressed nonalcoholic fatty liver disease development in high-fat diet-fed Syrian golden hamsters. Acta Pharmacol. Sin. 2019, 40, 895-907. [CrossRef] [PubMed]

199. Saveleva, E.; Tyutrina, E.; Nakanishi, T.; Tamai, I.; Salmina, A. The inhibitors of the apical sodium-dependent bile acid transporter (ASBT) as promising drugs. Biomeditsinskaya Khimiya 2020, 66, 185-195. [CrossRef] [PubMed]

200. Al-Dury, S.; Marschall, H.-U. Ileal Bile Acid Transporter Inhibition for the Treatment of Chronic Constipation, Cholestatic Pruritus, and NASH. Front. Pharmacol. 2018, 9, 931. [CrossRef] 